\title{
INFLUENCE OF THERMAL INSULATION ON THE ENERGY BALANCE FOR COLD-FORMED BUILDINGS
}

\author{
H. Gervásio ${ }^{1}$, P. Santos ${ }^{2, *}$, L. Simões da Silva ${ }^{3}$ and A.M.G. Lopes ${ }^{4}$ \\ ${ }^{1}$ ISISE, GIPAC Lda, Coimbra, Portugal \\ ${ }^{2}$ CICC, Civil Engineering Department, University of Coimbra, Coimbra, Portugal \\ ${ }^{3}$ ISISE, Civil Engineering Department, University of Coimbra, Coimbra, Portugal \\ ${ }^{4}$ ADAI, Mechanical Engineering Department, University of Coimbra, Coimbra, Portugal \\ *(Corresponding author: E-mail: pfsantos@dec.uc.pt)
}

Received: 31 December 2007; Revised: 22 July 2008; Accepted: 28 July 2008

\begin{abstract}
Two major factors contribute to the sustainability of buildings: material efficiency and energy efficiency. Material efficiency relates to the use of environmental-friendly materials and to the minimization of construction waste materials, either during construction and at the end-of-life stage of the building. Energy efficiency is currently understood as the optimization of the energy used during the operation stage of the building. This entails the energy needed for heating, cooling, lighting, etc. Often in order to improve the energy needs of a building, more insulation material is used, thus leading to a trade-off between embodied energy and operational energy. It is the aim of this paper to analyse and discuss the balance between the embodied energy and the operational energy for various levels of insulation, over its life cycle. The operational energy is estimated based on the simplified approach provided by the Portuguese Code of practice. The estimated operational energy is then balanced against the life cycle embodied energy of the system. Finally, the simplified approach for the calculation of the operational energy is confronted to more sophisticated dynamic simulations using the software EnergyPlus.
\end{abstract}

Keywords: Energy efficiency, Light steel residential buildings, Thermal insulation, Life-cycle energy analysis, Embodied energy, Operational energy

\section{INTRODUCTION}

Buildings are one of the major concerns regarding the sustainability of our habitat. The construction industry consumes materials and energy and is one of the main causes of pollution and resource depletion. According to the EU Communication "Towards a thematic strategy on the urban environment" [1], "(...)Heating and lighting of buildings accounts for the largest single share of energy use (42\%, of which $70 \%$ is for heating) and produces $35 \%$ of all greenhouse gas emissions. Buildings and the built environment use half of the material taken from the Earth's crust and are the source of 450 MT construction and demolition waste per year (over a quarter of all waste produced)(...) In Europe, people spend almost $90 \%$ of their time inside buildings. Poor design and construction methods can have a significant effect on the health of the building's occupiers and can produce buildings that are expensive to maintain, heat and cool, disproportionately affecting the elderly and less affluent social groups. Badly designed buildings such as housing estates can facilitate criminal behaviour.(...)"

The construction sector is of vital importance in our society and is a major contributor to socio-economic development in every country.

As the largest and most fragmented industry, the construction sector faces huge challenges in the pursuit of sustainability. Sustainable construction is a way for the industry to move towards achieving sustainable development, taking into account environmental, socio-economic and cultural issues. Sustainable construction ensures more economical use of finite raw materials and reduces and above all prevents the accumulation of pollutants and waste over the complete cycle of the building. Therefore, the use of environmentally friendly materials, cleaner construction 
methodologies, minimization and optimization of energy use, etc, are a major step towards the well being of the environment and foster sustainable development.

Several researchers have addressed the evaluation of the environmental impact of buildings over the entire life-cycle. Debnath et al. [2] presented a comparison of the embodied energy required for single and double storey residential buildings with load bearing walls, and four storey residential buildings with a reinforced concrete structure in India. They concluded that in India the embodied energy of construction materials in residential buildings is about $3-5 \mathrm{GJ} / \mathrm{m}^{2}$.

In Sweden, Adalberth [3] suggested a methodology for a life-cycle energy analyses and applied it to three prefabricated single-unit dwellings [4]. He found that $85 \%$ of total energy usage is required during the management phase leading to conclude that is essential to produce dwellings that requires small amounts of energy during this phase. A Canadian research [5] examined the embodied energy and greenhouse gas emissions associated with the on-site construction of alternative structural building assemblies based in different materials: wood, steel and concrete. Significant differences were found between the energy and greenhouse gas emissions associated with the construction of these structural assemblies, with concrete typically involving higher quantities.

In the UK, Eaton and Amato [6] performed a comparative life-cycle analysis of steel and concrete framed office buildings and concluded that there is no operational energy benefit in the passive thermal performance of modern concrete framed office buildings as compared with modern steel ones. Yohanis and Norton [7] studied the variation of life-cycle operational and embodied energy for a generic single-storey office building in the UK. They used a early design model to determine operational energy, capital cost and embodied energy and verify that capital and embodied energy costs as functions of glazing ratio do not vary significantly. More recently, Hacker et al. [8] investigated the effects of thermal mass and climate change on embodied and operational carbon dioxide emissions from a residential house in south-east England. The results presented there were indicative of the lifecycle $\mathrm{CO}_{2}$ savings and other performance benefits that can potentially be achieved by using heavyweight structural elements to provide thermal mass in housing. However these results are related to a particular dwelling with specific assumptions for several variables.

A recent study by Utama and Gheewala [9] focused on life-cycle energy of single storey houses, particularly on the effect of enclosure materials associated with air-conditioning, trying to identify the best practice of common construction materials used in Indonesia. They verify that materials having low initial embodied energy do not automatically have low life cycle energy and concluded that the best option for reducing life-cycle energy would be having lightweight enclosure materials (medium density and less thickness) leading to less time lag and also having low U-value.

In Israel, Huberman and Pearlmutter [10] performed a life-cycle energy analysis of building materials in the Negev desert region. They concluded that traditional local building materials (well-insulated stabilized soil blocks) may optimize the building's energy requirements over its entire life cycle, by analyzing both embodied and operational energy consumption comparing several possible alternatives. The cumulative energy saved over a 50-year life cycle by this material substitution was around $20 \%$.

All these studies were carried out for a relatively small number of specific climatic regions. According to the subdivision of climatic regions presented by IPCC [11] for the various continents, only a few are represented in these studies. In addition, for the UK, contradictory conclusions are obtained, namely with respect to the benefits of the use of heavyweight structural elements to provide thermal mass in residential buildings. In the coastal region of Portugal there is a void in 
respect to life-cycle energy analysis of buildings. This work intends to partially fill this void, analysing a real residential lightweight steel building located in Portugal and making use of typical local climatic conditions to compute the operational energy needed in order to secure the thermal comfort of occupants (heating and cooling). It is well known that in the quantification of the life-cycle energy use by buildings, the operational energy needs to be considered along with the embodied energy of the building materials. The improvement of the thermal behaviour of a building usually requires the utilisation of more insulation materials, which, in turn, increase the embodied energy of the system. The analysis of the trade-off between the operational energy and the embodied energy of a building is one of the main purposes of this paper. This should provide directives for the improvement of the thermal efficiency of modern Portuguese residential buildings in order to minimize the total life cycle building energy.

The structure of this paper is presented next. Firstly, a brief description of the major steps in life cycle analysis and an outline of the methodology for the evaluation of the energy efficiency of residential buildings is presented. Subsequently, using a real lightweight residential building in Portugal, a reference case is analysed. Finally, a parametric study is carried out, whereby increasing levels of insulation are used to assess the trade-off between energy efficiency and life cycle embodied energy.

\section{LIFE CYCLE ANALYSIS}

\section{$2.1 \quad$ Introduction}

A Life Cycle approach entails the analysis of one or more criteria through the complete life cycle of a building. The complete life cycle of a building, represented in Figure 1, includes all the stages from raw material acquisition, through material production, construction and operation, to demolition and management of construction waste. A life cycle analysis should also include the intermediate phases, such as the transportation of materials and equipment from one place to the other.

In this paper, the criterion for the life cycle analysis is the energy requirement of a building. Two types of energy are going to be quantified: the embodied energy of the building and the operational energy.

The embodied energy of a material refers to the energy used to extract and process the raw materials in order to produce it. A building is usually composed of several types of materials, each of which contributes to the building's total embodied energy. In this analysis, and considering the building's life, the life cycle embodied energy refers to the energy needed to produce the materials, the energy required to construct and repair the building during its use stage, and the energy related to the end-of-life of the building. The energy due to the transportation of materials and equipment is also included in the life cycle analysis. The building's embodied and operational energy are represented in Figure 1.

The operational energy is hereby referred to the energy required to operate the building during its use phase. Thus, the operational energy entails the energy needed to condition the building (to heat, cool and/or ventilate), the energy needed for illumination and power equipment, and the energy needed for other services. In Figure 1, the operational energy refers only to the use phase in the building's cycle. 
The embodied energy content of a building is usually considered to be small when compared with the energy required for operating the building over its cycle, although in some cases the embodied energy can be equivalent to many years of operational energy [12]. In fact, as developments in the energy efficiency of the building envelope become more effective, the embodied energy becomes more and more important.

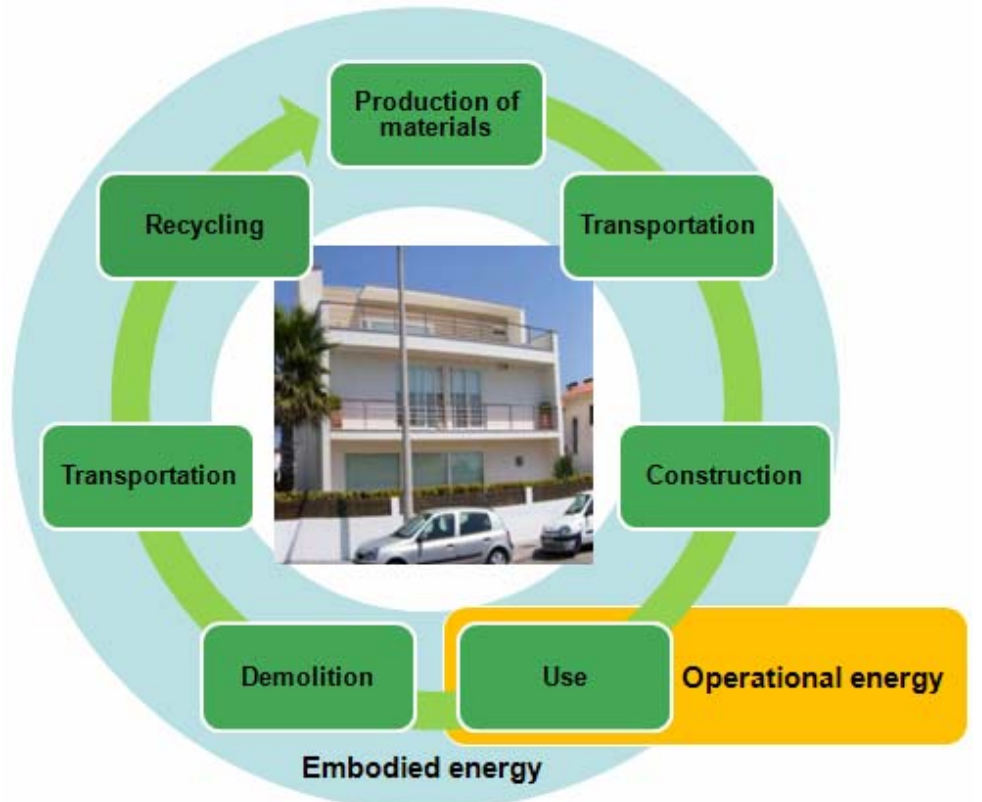

Figure 1. Life Cycle Analysis of the Building

\subsection{Life Cycle Assumptions}

A life cycle analysis implies a long time period for the analysis. Regarding buildings, assuming a service life of 50 years, the time period of the analysis should include these 50 years, plus the time needed for the production of the materials and the assemblage of the building, and the time needed for the demolition of the structure. However, for the sake of simplification, it is assumed that the time period of the analysis is 50 years. It is further considered that the production of materials and the construction of the building take place in year 0 , and that the demolition of the building occurs 50 years later.

The use stage relates to the interval of years between the construction and the demolition of the structure, and includes the maintenance and repair operations, which are necessary over to maintain the building in the required condition. These operations are usually estimated based on common practice. In the following case study, and according to information provided by a manufacturer, it is assumed that the Exterior Insulation Finishing System (EIFS) of the building needs to be repaired every 25 years.

The end-of-life stage is probably the phase more difficult to analyse, particularly in construction facilities with a long life span. Steel is $100 \%$ recyclable and scrap can be converted to the same quality steel depending upon the recycling process. Thus, in this paper it is assumed that, at the end-of-life stage, the structure will be demolished and steel is going to be recycled with a recycling rate of $80 \%$. The recovery of steel scrap for recycling allows allocating a credit to the arising scrap. The credit, or benefit, is due to the fact that the production of secondary steel from scrap (in the Electric Arc Furnace route) avoids the production of primary steel from the Blast Furnace route. The approach followed in this case study is the closed material loop recycling methodology proposed by the International Iron and Steel Institute [13]. All the remaining materials are assumed to be sent to landfill. 


\section{ENERGY EFFICIENCY OF RESIDENTIAL BUILDINGS}

\subsection{Introduction}

The European Directive on the Energy Performance of Buildings (EPBD) [14] is one of the main legislative instruments affecting the building sector in Europe. The directive is designed to promote the energy performance of buildings in member states by introducing a framework for an integrated methodology for measuring energy performance; application of minimum standards in new buildings and certain renovated buildings, and regular updating of these; energy certification and advice for new and existing buildings; and inspection and assessment of boilers and heating/cooling systems. The directive entered into force on the $4^{\text {th }}$ of January, 2003.

To support the implementation of the EPBD in European Member States, the European standards body, CEN, has been developing a series of standards. Among these, the standard for the calculation of energy use for space heating and cooling is EN ISO 13790 [15]. This standard provides calculation methods for the assessment of the energy used for space heating and cooling of residential and non-residential buildings. Calculation procedures are included for the quantification of: (i) heat transfer by transmission and ventilation of the building; (ii) solar gains and its contribution to the building heat balance; and (iii) annual energy needs for heating and cooling. Two main types of calculation methods are available in ISO 13790: quasi-steady state methods, calculating the heat balance over a sufficiently long period of time in order to ignore heat stored and released; and, dynamic methods, calculating the heat balance with short periods (e.g. hourly) and considering the heat stored and released from the mass of the building. In the category of quasi-steady state methods the standard provides a monthly and a seasonal method. In the category of dynamic methods, the standard provides a simplified approach based on a hourly dynamic procedure, and calculation procedures for a more detailed approach based on simulation methods. Consistency in the application of the methods provided in the standard is ensured by a maximum of common procedures and descriptions, boundary conditions and input data.

The adoption of the EPBD in Portugal led to the reformulation of previous codes and to the publication in 2006 of a new Code of Practice for the thermal behavior of residential and small commercial buildings [16], and a new Code of Practice for buildings with HVAC power higher than $25 \mathrm{~kW}$ [17]. Both codes have been developed according to the specifications of the European Standard EN ISO 13790 [15].

\subsection{Simplified Quasi Steady-State Analysis}

The methodology adopted in this paper for the calculation of the energy needs for heating and the energy needs for cooling, is provided by the Portuguese code of practice "Regulamento das Características de Comportamento Térmico dos Edificios (RCCTE)" [16], hereafter referred to as RCCTE. The methodology was developed according to the European Standard EN ISO 13790 [15] with the adaptations needed to comply with the reality of construction and current operation of buildings in Portugal.

The RCCTE methodology follows a quasi-steady approach and energy needs are calculated per year, considering a heating season and a cooling season. In the following paragraphs the RCCTE methodology is described, but before that, a brief overview of ISO 13790 is given in order to introduce the general framework for the calculation procedures. The seasonal ("quasi-steady state") approach of ISO 13790 is considered, in which dynamic effects are taken into account by introducing correlation factors. Therefore, considering the heating season, the energy needs for space heating, $\left(\mathrm{Q}_{\mathrm{H}, \mathrm{nd}}\right)$, in $M J$, is given by 


$$
\mathrm{Q}_{\mathrm{H}, \mathrm{nd}}=\mathrm{Q}_{\mathrm{H}, \mathrm{ht}}-\eta_{\mathrm{H}, \mathrm{gn}} \mathrm{Q}_{\mathrm{H}, \mathrm{gn}}
$$

where $Q_{H, h t}$ is the total heat transfer for the heating mode, $Q_{H, g n}$ are the total heat gains for the heating mode, and $\eta_{H, g n}$ is the utilization factor for the internal and solar heat gains. The gain utilization factor $\left(\eta_{H, g n}\right)$ takes into account that only part of the gains are utilized to decrease the energy need for heating, the rest leading to an undesired increase of the internal temperature. This factor is a function of the gain/loss ratio $\left(\gamma=Q_{g n} / Q_{h t}\right)$ and a numerical parameter $(\tau)$ that depends on the time constant of the building (building inertia), and is illustrated in Figure 2.

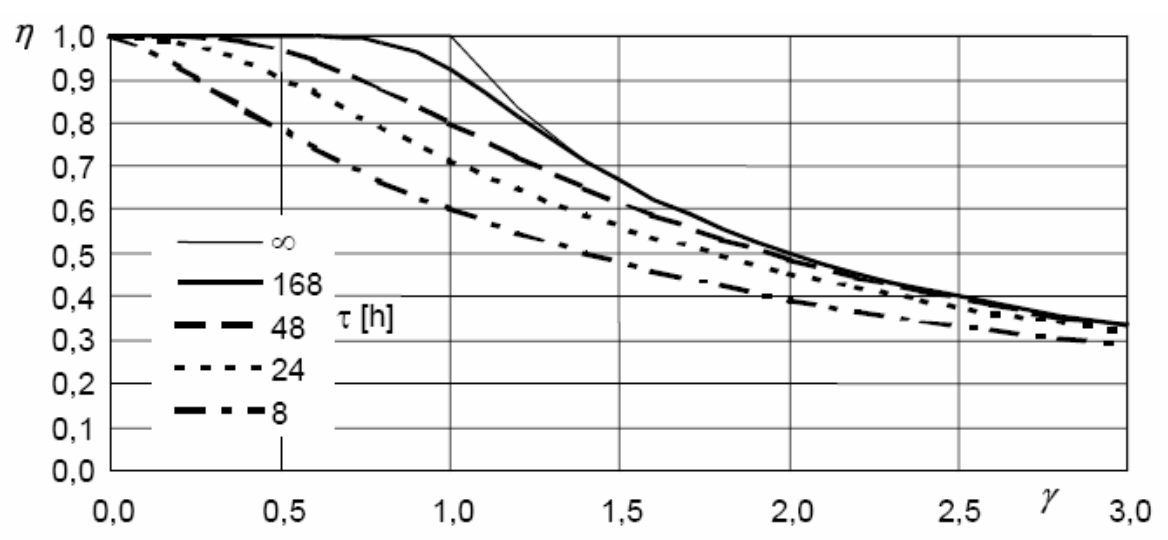

Figure 2. Gain Utilization Factor for Heating [15]

For the cooling season, the energy needs for cooling $\left(Q_{C, n d}\right)$, in $M J$, may be obtained by two different ways, corresponding to the same method and leading to the same result:

i) by the use of a utilisation factor for losses (mirror image of the approach for heating)

$$
\mathrm{Q}_{\mathrm{C}, \mathrm{nd}}=\mathrm{Q}_{\mathrm{C}, \mathrm{gn}}-\eta_{\mathrm{C}, \mathrm{ss}} \mathrm{Q}_{\mathrm{C}, \mathrm{ht}}
$$

where $Q_{C, g n}$ are the total heat gains for the cooling mode, $Q_{C, h t}$ is the total heat transfer for the cooling mode, and $\eta_{C, l s}$ is the loss utilization factor, which takes into account that only part of the transmission and ventilation heat transfer is used to decrease the cooling needs;

ii) by the use of a utilisation factor for gains (similar to the heating utilization factor)

$$
\mathrm{Q}_{\mathrm{C}, \mathrm{nd}}=\left(1-\eta_{\mathrm{C}, \mathrm{gn}}\right) \mathrm{Q}_{\mathrm{C}, \mathrm{gn}}
$$

where $\eta_{C, g n}$ is the gain utilization factor, which takes into account the fact that only part of the gains is compensated by thermal heat transfer by transmission and ventilation assuming a certain maximum internal temperature. The curves for $\eta_{C, g n}$ are the same as for $\eta_{H, g n}$ (see Figure 2).

For each mode, heating mode $(\mathrm{H})$ or cooling mode $(\mathrm{C})$, the total heat transfer $\left(Q_{h t}\right)$ of a space zone and for a given calculation period is given by the sum of the heat transfer by transmission through the wrapped components $\left(Q_{t r}\right)$ and the total heat transfer by ventilation $\left(Q_{v e}\right)$, given by, in $M J$,

$$
\mathrm{Q}_{\mathrm{ht}}=\mathrm{Q}_{\mathrm{tr}}+\mathrm{Q}_{\mathrm{ve}}
$$

The total heat gains $\left(Q_{g n}\right)$, over the given period, are given by the sum of the internal heat sources $\left(Q_{i n t}\right)$, and the sum of the solar heat gains $\left(Q_{s o l}\right)$, in $M J$, 


$$
\mathrm{Q}_{\mathrm{gn}}=\mathrm{Q}_{\text {int }}+\mathrm{Q}_{\mathrm{sol}}
$$

The same procedure was adopted in RCCTE. Two main parameters are quantified: the annual nominal energy needs for heating $\left(N_{i c}\right)$ and the annual nominal energy needs for cooling $\left(N_{v c}\right)$. The code also provides maximum allowable annual values for heating $\left(N_{i}\right)$ and for cooling $\left(N_{v}\right)$. The requirement regarding the maximum values should be verified taking into consideration the limit values of thermal quality, which are given in terms of maximum allowable values of the thermal transmittance $(U)$ of the different elements. The limit values of $N_{i}$ and $N_{v}$ depend on the climatic characteristics of the location of the building and its geometrical shape. For the quantification of this and other parameters, the country is divided into three climatic zones for the heating season and three climatic zones for the cooling season, represented in Figure 3.

For the quantification of annual energy needs, the criteria for thermal comfort in RCCTE specify a set-point temperature for the heating season of $20^{\circ} \mathrm{C}$ and a set-point temperature for the cooling season of $25^{\circ} \mathrm{C}$, independently of the climatic zone of the country.

In RCCTE, the length of the heating season depends on the location of the building in the country, according to Figure 3. It may vary from 4.3 months, for the least severe zone, to 6 months, in the most severe one. Similarly to Eq. 1, the quantification of the annual energy needs for heating $\left(N_{i c}\right)$ is given, per net area of the floor, in $k W h / m^{2}$, as

$$
N_{i c}=\left(Q_{h t}-\eta \cdot Q_{g n}\right) / A_{p} \quad \text { and } \quad N_{i c}<N_{i}
$$

where $Q_{h t}$ and $Q_{g n}$ have the same meaning as in Eq. 1 and $\eta$ is the gain factor, defined later in Eq. 14.

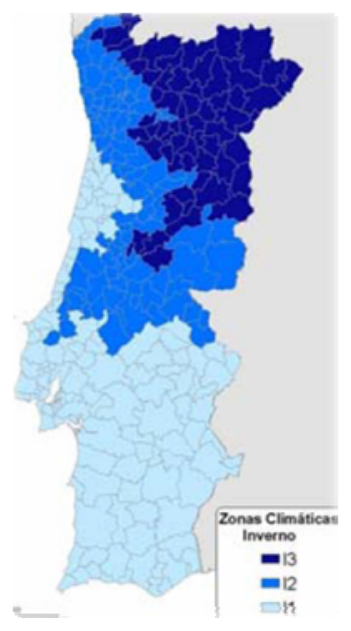

(a) Heating season

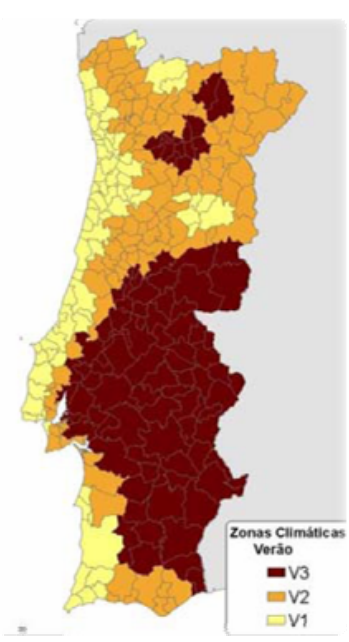

(b) Cooling season

Figure 3. Portuguese Climatic Zones (according to RCCTE)

The heat transfer by transmission $\left(Q_{\mathrm{tr}}\right)$, in $k W h$, is given by the sum of: (i) the heat transfer from the conditioned space to the exterior $\left(Q_{\text {ext }}\right)$; (ii) the heat transfer from the conditioned space to an adjacent unconditioned space $\left(Q_{\mathrm{lna}}\right)$; (iii) the heat transfer through the ground floor $\left(Q_{\mathrm{pe}}\right)$; and (iv) the heat transfer by thermal bridges $\left(Q_{\mathrm{pt}}\right)$, given by

$$
Q_{\mathrm{tr}}=Q_{\mathrm{ext}}+Q_{\mathrm{lna}}+Q_{\mathrm{pe}}+Q_{\mathrm{pt}}
$$


For the calculation of heat transfer rate through the envelope of the building $\left(Q_{e x t}\right)$ (e.g. walls, roof, floor, windows), the following expression, in $W$, may be used,

$$
Q_{\text {ext }}=\mathrm{U} \cdot \mathrm{A} \cdot\left(\theta_{\mathrm{i}}-\theta_{\mathrm{atm}}\right)
$$

or, considering the degree-days (in ${ }^{\circ} \mathrm{C} \cdot$ days), the heat transfer, in $k W h$, is given by

$$
Q_{\mathrm{ext}}=0.024 \cdot \mathrm{U} \cdot \mathrm{A} \cdot \mathrm{GD}
$$

where, $U$ is the thermal transmittance of the element of the building envelope (in $\mathrm{W} / \mathrm{m}^{2} \cdot{ }^{\circ} \mathrm{C}$ ), $\mathrm{A}$ is the corresponding area (in $\mathrm{m}^{2}$ ), $\theta_{i}$ is the set-point temperature of the building for heating (in ${ }^{\circ} \mathrm{C}$ ), and $\theta_{\text {atm }}$ is the outside air temperature (in ${ }^{\circ} \mathrm{C}$ ). Similar expressions are used for the calculation of the remaining components in Eq. 7.

The heat transfer rate due to the ventilation $\left(Q_{r a}\right)$, in $W$, is given by

$$
Q_{\mathrm{ra}}=\rho \cdot C_{p} \cdot R_{\mathrm{ph}} \cdot \mathrm{V} \cdot\left(\theta_{\mathrm{i}}-\theta_{\mathrm{atm}}\right) / 3600
$$

where $\rho$ is the air density (in $\mathrm{kg} / \mathrm{m}^{3}$ ), $\mathrm{C}_{\mathrm{p}}$ is the air specific heat capacity (in $\mathrm{J} / \mathrm{kg} \cdot{ }^{\circ} \mathrm{C}$ ), $R_{p h}$ is the air exchange rate in the conditioned space (in $h^{-1}$ ), $V$ is the interior volume of the building (in $\mathrm{m}^{3}$ ), and $\cdot \theta_{i}$ and $\theta_{\text {atm }}$ are the set-point temperature of the building for heating and the outside air temperature (in ${ }^{\circ} \mathrm{C}$ ), respectively. Considering the volumetric heat capacity of air,

$\rho \cdot C_{\mathrm{p}}=1200 \mathrm{~J} /\left(\mathrm{m}^{3} \cdot \mathrm{K}\right)$

and the degree-days, GD (in ${ }^{\circ} \mathrm{C} \cdot$ days), the energy needed to compensate these losses during the heating season, $Q_{v e}\left(=Q_{r a}\right)$, is given by, in $k W h$,

$$
Q_{\mathrm{ve}}=0.024 \cdot\left[0.34 \cdot\left(R_{\mathrm{ph}} \mathrm{V} \cdot \mathrm{GD}\right)\right]
$$

Eq. 11 is only valid for natural ventilation, without any mechanical equipment.

For the heating season, the heat gains are obtained from internal sources and from solar heat, as indicated in Eq. 4. Internal heat gains $\left(Q_{\text {int }}\right)$ include metabolic heat from occupants and dissipated heat from appliances, lighting devices and other equipments. According to RCCTE, the internal heat gains are given by (in $k W h$ ),

$$
Q_{\text {int }}=q_{i} \cdot M \cdot A_{\mathrm{p}} \cdot 0.72
$$

where $M$ is the length of the heating season (in months); $A_{p}$ is the net area of the floor (in $m^{2}$ ); and $q_{i}$ is average internal heat gains per unit of the net area of the floor (in $W / \mathrm{m}^{2}$ ). The internal heat gains may vary considerable; however, for certain types of buildings, RCCTE provides tabulated values. For instance, for residential buildings, it may be assumed that $q_{i}=4 \mathrm{~W} / \mathrm{m}^{2}$.

The solar heat gains in RCCTE are given by the gains through glazed elements, according to the following expression, in $\mathrm{kWh}$ :

$$
Q_{s o l}=G_{s u l} \sum_{j}\left[X_{j} \sum_{n} A_{s n j}\right] \cdot M
$$


where $G_{\text {sul }}$ is the monthly average of the solar energy irradiation in a vertical surface facing south, per unit of area, during the heating season (in $\mathrm{kWh} / \mathrm{m}^{2}$ ); $X_{j}$ is a factor depending on the orientation of the surface; $A_{s n j}$ is the effective collecting area of surface $n$ with orientation $j$ (in $m^{2}$ ); and $M$ is the length of the heating season (in months). The value of $G_{s u l}$ is given in RCCTE for each region in Portugal. The effective collecting area $\left(A_{s n j}\right)$ may be affected by factors taking into account the shading reduction due to external obstacles, the window characteristics and the properties of the glazing.

To take into account dynamic effects, the gain utilisation factor is given by,

$$
\left\{\begin{array}{c}
\eta=\frac{1-\gamma^{a}}{1-\gamma^{a+1}} \quad \text { if } \quad \gamma \neq 1 \\
\eta=\frac{a}{a+1} \quad \text { if } \quad \gamma=1
\end{array}\right.
$$

This factor is dependent on the thermal inertia of the building and on the heat balance ratio, given by $\gamma=Q_{g n} / Q_{h t}$. RCCTE provides values for the parameter $a$ according to the inertia of the building. Thus, for buildings with weak thermal inertia, $a=1.8$; for buildings with medium thermal inertia, $a=2.6$; and for buildings with strong thermal inertia, $a=4.2$.

For the cooling season, RCCTE follows a similar approach as for the heating season. In this case, the length of the cooling season is assumed to be four months, from June to September, for all zones of the country. RCCTE adopts the $2^{\text {nd }}$ approach of the ISO standard 13790. Thus, from (3), the energy needed to keep the building at the set-point temperature, during these four months, in $\mathrm{kWh} / \mathrm{m}^{2}$, is given by,

$$
N_{v c}=Q_{g n}(1-\eta) / A_{p} \quad \text { and } \quad N_{v c}<N_{c}
$$

The heat gains of the building, in this case, are given by the sum of internal gains $\left(Q_{i n t}\right)$, solar gains $\left(Q_{\text {sol }}\right)$, gains through ventilation $\left(Q_{v e n t}\right)$ and gains by transmission $\left(Q_{t r}\right)$ through the envelope of the building.

\subsection{Advanced Simulation Analysis}

The advanced simulation analysis is performed using the DesignBuilder software [18], which uses the EnergyPlus software [19] as the engine for the dynamic thermal simulation. EnergyPlus is an energy analysis and thermal load simulation program, with several important computational features such as, integrated simultaneous solution; sub-hourly, user-definable time steps; heat balance based solution; transient heat conduction; improved ground heat transfer modelling; combined heat and mass transfer; thermal comfort models; anisotropic sky model; advanced fenestration calculations; day lighting controls; loop based configurable HVAC systems and atmospheric pollution calculations, etc. These features, although not representing a fully dynamic simulation such as would be obtained using CFD technique, allow obtaining reasonably precise and realistic simulation results. EnergyPlus has been extensively tested and validated since 1999 [20] and is now rated as a reference simulation tool for sub-dynamic thermal simulation [21, 22]. EnergyPlus was also recently rated as the best energy simulation program for the evaluation of the energy flows through windows [23]. 


\section{REFERENCE EXAMPLE: LIGHT STEEL RESIDENTIAL BUILDING}

\subsection{General Description}

The case study focuses on a single-family dwelling with 2 main floors, with an area of $165 \mathrm{~m}^{2}$ each, and a smaller top floor with an area of $115 \mathrm{~m}^{2}$, located in central Portugal and illustrated in Figure 4.

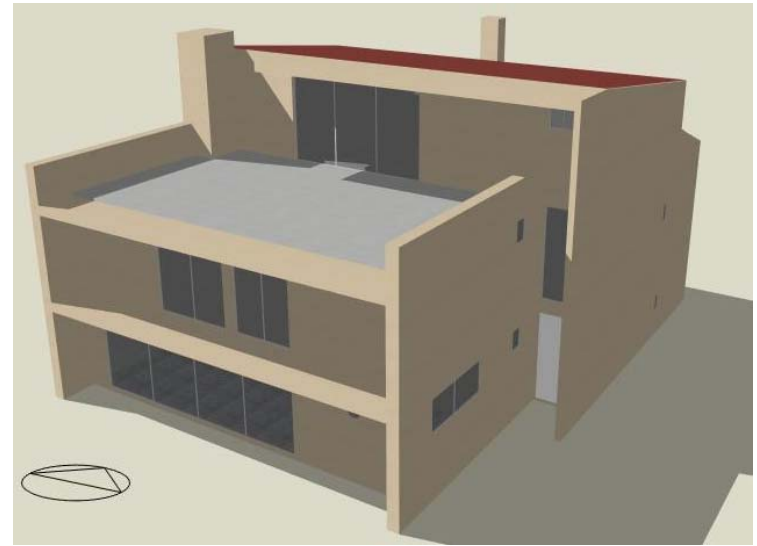

Southern and Eastern Views

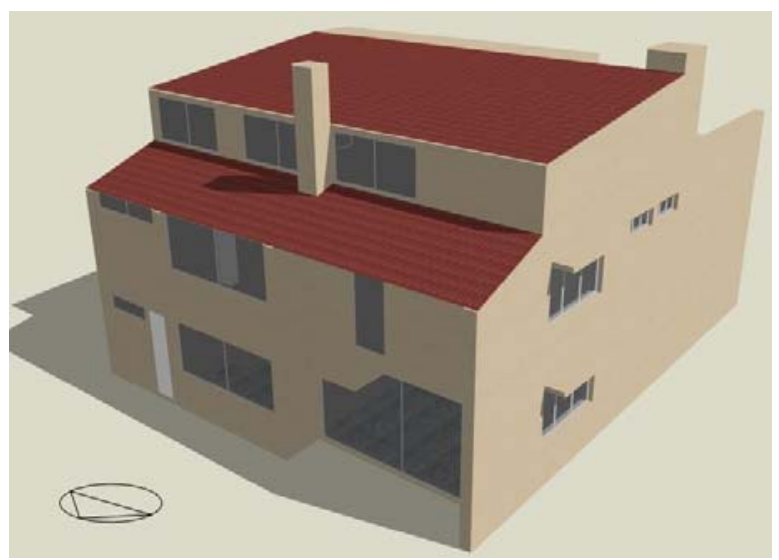

Northern and Western Vviews

Figure 4. Elevation Views of the Building

The building frame consists of a steel structure formed by cold formed steel profiles, designed for a service life of 50 years according to the Structural Eurocodes [24]. The total internal net space is $361 \mathrm{~m} 2$. The ground floor is composed of a living-dining room, a small office, a kitchen, a small pantry, two bathrooms and stairs (see Figure 5). The first floor has 4 bedrooms, 4 bathrooms and stairs. The top floor has one master bedroom and one bathroom. The main facade of the house faces south.
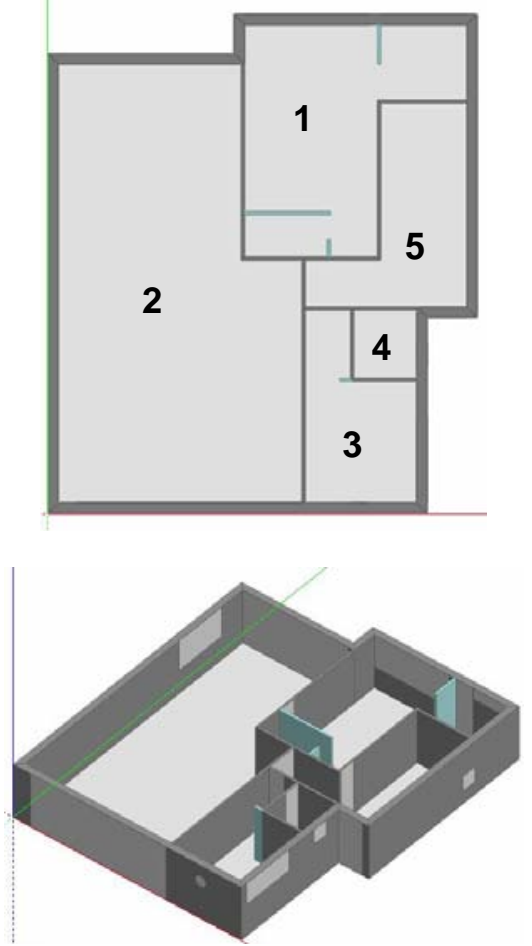

Ground floor
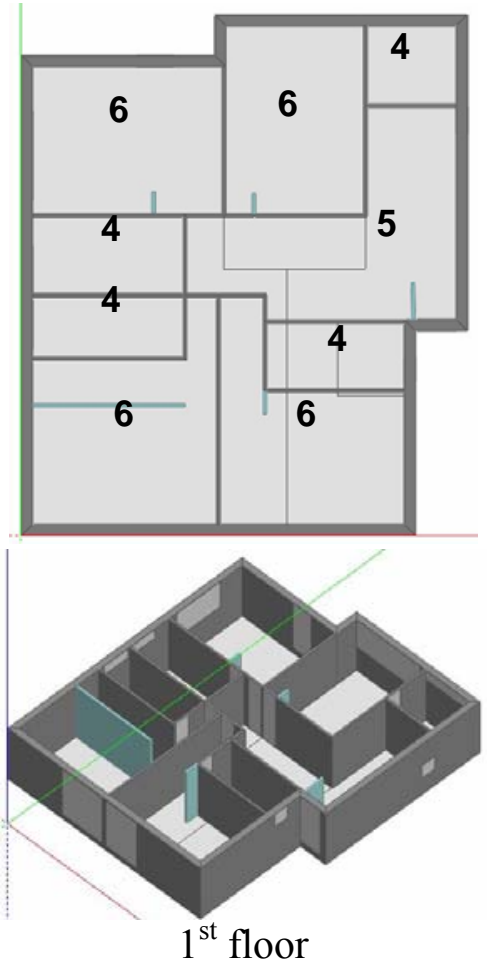

Figure 5. Layout of the Floors

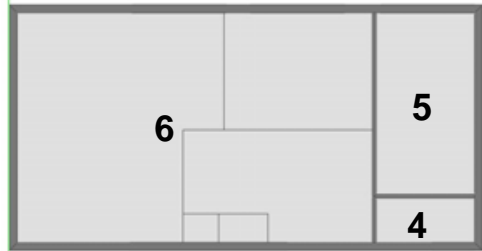

1 - Kitchen

2 - Dining / Living room

3 - Office room

4 - WC

5 - Corridor / Stairs

6 - Bedroom

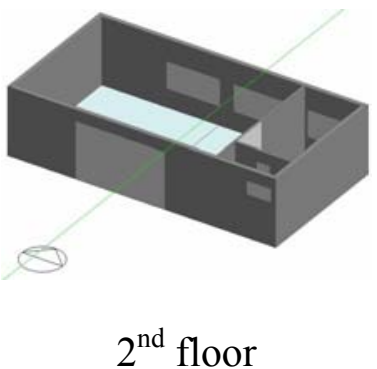


The characteristics of the building components are described in the following paragraphs. The external walls are made of an outside layer of Oriented Strand Board (OSB) panels, $11 \mathrm{~mm}$ thick, and an inside layer of gypsum boards with a thickness of $15 \mathrm{~mm}$. The gap between the two panels is filled with rock wool $140 \mathrm{~mm}$ thick. The internal walls are made of gypsum boards with a thickness of $15 \mathrm{~mm}$ and a layer of rock wool with a thickness of $70 \mathrm{~mm}$. The slabs are made of composite panels with a top layer of OSB panels $(15 \mathrm{~mm})$, an intermediate layer of rock wool 70 $\mathrm{mm}$ thick, and a bottom layer of gypsum boards $13 \mathrm{~mm}$ thick. The ground floor is made of a light-concrete slab over a layer of gravel. The terrace floor is made of a top layer of OSB panels 18 $\mathrm{mm}$ thick, covered by $40 \mathrm{~mm}$ of cast concrete and a ceramic finish, an intermediate layer of rock wool $140 \mathrm{~mm}$ thick, and a bottom layer of gypsum boards $13 \mathrm{~mm}$ thick. The rock wool insulation panels completely clad the steel frame ensuring that the house achieves high thermal and acoustic behaviour according to regulatory requirements. The envelope of the house is covered by an Exterior Insulation and Finish System (EIFS). The quantities of the main materials estimated for the construction are indicated in Table 1.

Table 1. Bill of Materials

\begin{tabular}{|c|c|c|}
\hline Material & Quantities & Unit \\
\hline Concrete C25/30 & 70680 & $\mathrm{~kg}$ \\
\hline Cold formed steel & 19494 & $\mathrm{~kg}$ \\
\hline Rock wool $\left(50 \mathrm{~kg} / \mathrm{m}^{3}\right)$ & 6167 & $\mathrm{~kg}$ \\
\hline Gypsum plasterboard $\left(600 \mathrm{~kg} / \mathrm{m}^{3}\right)$ & 6340 & $\mathrm{~kg}$ \\
\hline Oriented strand board $\left(650 \mathrm{~kg} / \mathrm{m}^{3}\right)$ & 7016 & $\mathrm{~kg}$ \\
\hline Steel reinforcement & 1307 & $\mathrm{~kg}$ \\
\hline \multicolumn{3}{|c|}{ Exterior Insulation and Finish System (EIFS): } \\
\hline Polystyrene board $\left(30 \mathrm{~kg} / \mathrm{m}^{3}\right)$ & 297 & $\mathrm{~kg}$ \\
\hline Finish Coat (acrylic) & 330 & $\mathrm{~m}^{2}$ \\
\hline
\end{tabular}

\subsection{Climatic Data}

Geographically, continental Portugal is located between latitudes $37^{\circ}$ and $42^{\circ} \mathrm{N}$ and longitudes of $9.5^{\circ}$ and $6.5^{\circ} \mathrm{W}$. The maximum altitude is $2000 \mathrm{~m}$. The country has a diverse climate from north to south and from east to the west coast. The north part of the country has an Atlantic climate with cold and wet winters. The central regions have a mixture of Atlantic and Mediterranean climates, with mild winters and hot and dry summers, particularly in the inner regions. The southern part of the country has a very dry climate with mild winters.

According to the Portuguese Instituto de Meteorologia [25], the annual average of the air temperature varies regularly over the year, reaching the highest values in August and the minimum values in January. In the summer, the values of the average maximal temperature vary between $16^{\circ} \mathrm{C}$ in the highest mountain (inner central-northern region) and from $32^{\circ} \mathrm{C}$ to $34^{\circ} \mathrm{C}$ in the inner central-southern part of the country. The values of the average minimal temperature, during winter, vary between $2{ }^{\circ} \mathrm{C}$ in the inner high lands and $12^{\circ} \mathrm{C}$ in the south. The rain values vary from the northern part to the southern part of the country. On average, about $42 \%$ of the annual rainfall occurs during the winter (December-February), while the lowest values happen during summer (July and August) with a share of $6 \%$ of the annual rainfall. 


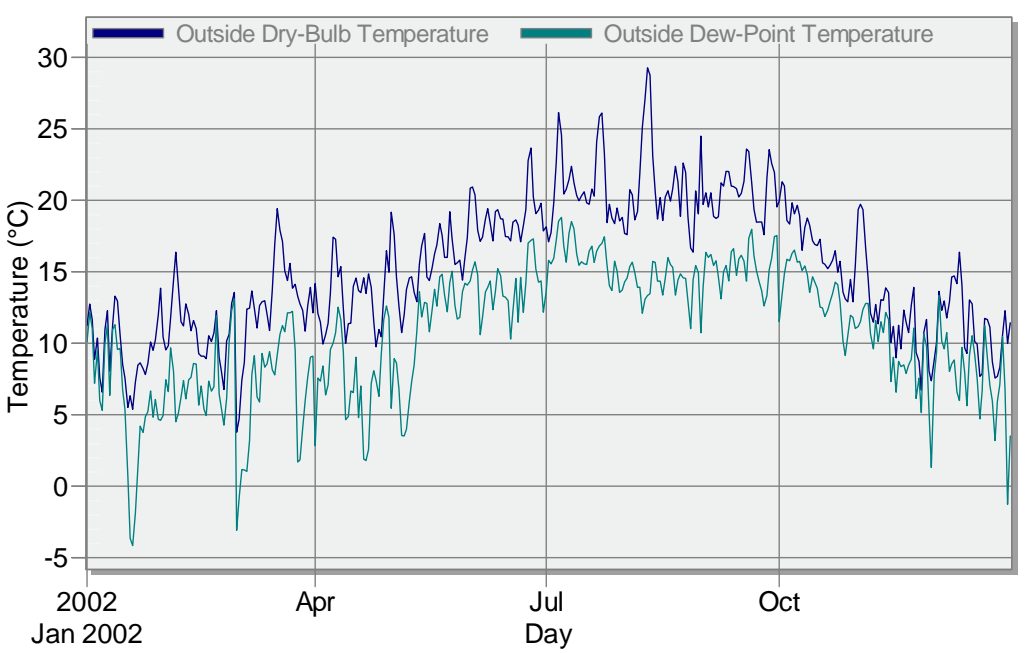

Figure 6. Annual Outside Air Temperature for Coimbra (Reference Year 2002)

Coimbra is located in central Portugal. According to Figure 2, Coimbra is located in heating zone I1 and cooling zone V2. The annual variation of the outside temperature, according to data from EnergyPlus, is shown in Figure 6. The length of the heating season is 6 months and the corresponding degree-days are 1834 (base $20^{\circ} \mathrm{C}$ ).

\subsection{Life Cycle Energy Analysis}

\subsubsection{Thermal characteristics of the building components}

Table 2 indicates the geometric characteristics of the different elements of the building and the corresponding thermal properties.

Table 2. Thermal Transmittances of the Building Components

\begin{tabular}{|c|c|c|c|}
\hline & Material & Thickness & $\mathrm{U}\left(\mathrm{W} / \mathrm{m}^{2} .{ }^{\circ} \mathrm{C}\right)$ \\
\hline \multirow{4}{*}{ External walls } & Gypsum board & $15 \mathrm{~mm}$ & \multirow{4}{*}{0.218} \\
\hline & Rock wool & $140 \mathrm{~mm}$ & \\
\hline & OSB & $11 \mathrm{~mm}$ & \\
\hline & Exterior Insulation and Finish System (EIFS) & $33 \mathrm{~mm}$ & \\
\hline \multirow{3}{*}{ Internal walls } & Gypsum board & $15 \mathrm{~mm}$ & \multirow{3}{*}{0.479} \\
\hline & Rock wool & $70 \mathrm{~mm}$ & \\
\hline & Gypsum board & $15 \mathrm{~mm}$ & \\
\hline \multirow{4}{*}{ Roof } & Gypsum board & $15 \mathrm{~mm}$ & \multirow{4}{*}{0.262} \\
\hline & Rock wool & $140 \mathrm{~mm}$ & \\
\hline & OSB & $11 \mathrm{~mm}$ & \\
\hline & Ceramic tiles & $15 \mathrm{~mm}$ & \\
\hline \multirow{5}{*}{ Terrace } & Gypsum board & $15 \mathrm{~mm}$ & \multirow{5}{*}{0.253} \\
\hline & Rock wool & $140 \mathrm{~mm}$ & \\
\hline & OSB & $18 \mathrm{~mm}$ & \\
\hline & Cast concrete & $40 \mathrm{~mm}$ & \\
\hline & Ceramic & $10 \mathrm{~mm}$ & \\
\hline \multirow{3}{*}{ Internal floor } & Gypsum board & $15 \mathrm{~mm}$ & \multirow{3}{*}{0.252} \\
\hline & Rock wool & $140 \mathrm{~mm}$ & \\
\hline & OSB & $18 \mathrm{~mm}$ & \\
\hline Windows & Double pane clear glass & $6 / 14 / 4 \mathrm{~mm}$ & 2.733 \\
\hline
\end{tabular}




\subsubsection{Operational Energy}

The operational energy, in this case study, is the energy needed for heating and cooling the building, according to the requirements of RCCTE, during the use stage of the building (see Figure 1). The quantification of the operational energy considers a time period for the analysis of 50 years. According to RCCTE, the whole building may be considered a unique thermal zone, which is kept continuously at a constant set-point temperature of $20^{\circ} \mathrm{C}$ and $25^{\circ} \mathrm{C}$, respectively, for the heating season and for the cooling season. The annual energy need for heating, given from (1), is summarized in Table 3.

Table 3. Annual Energy Need for Heating $\left(\mathrm{Q}_{\mathrm{H}, \mathrm{nd}}\right)$

\begin{tabular}{|c|c|c|}
\hline \multirow{2}{*}{$\begin{array}{c}\text { Heat losses } \\
(\mathrm{kWh} / \text { year })\end{array}$} & Exterior walls & 2137.86 \\
\cline { 2 - 3 } & Roof and Terrace & 1578.85 \\
\cline { 2 - 3 } & Windows/Doors & 10562.96 \\
\cline { 2 - 3 } & Ventilation & 6989.74 \\
\cline { 2 - 3 } & Total & $\mathbf{2 1 2 6 9 . 4 1}$ \\
\hline \multirow{2}{*}{$\begin{array}{c}\text { Heat gains } \\
\text { (kWh/year) }\end{array}$} & Internal & 5468.08 \\
\cline { 2 - 3 } & Solar & 12334.20 \\
\cline { 2 - 3 } & Total & $\mathbf{1 7 8 0 2 . 2 8}$ \\
\hline \multicolumn{2}{|c|}{$\eta$} & 0.70 \\
\hline \multicolumn{2}{|c|}{ Heating energy (kWh/year) } & $\mathbf{8 8 3 5 . 6 7}$ \\
\hline
\end{tabular}

Given a total net floor area of $316.44 \mathrm{~m}^{2}$, the annual energy need for heating, per $\mathrm{m}^{2}$, is obtained from Eq. 6, and its value should be less than the limit value of $N_{i}$ :

$$
N_{i c}=27.92 \mathrm{kWh} / \mathrm{m}^{2} . \text { year }<N_{i}=81.08 \mathrm{kWh} / \mathrm{m}^{2} . \text { year }
$$

The energy need for heating, per year, is represented in Figure 7.

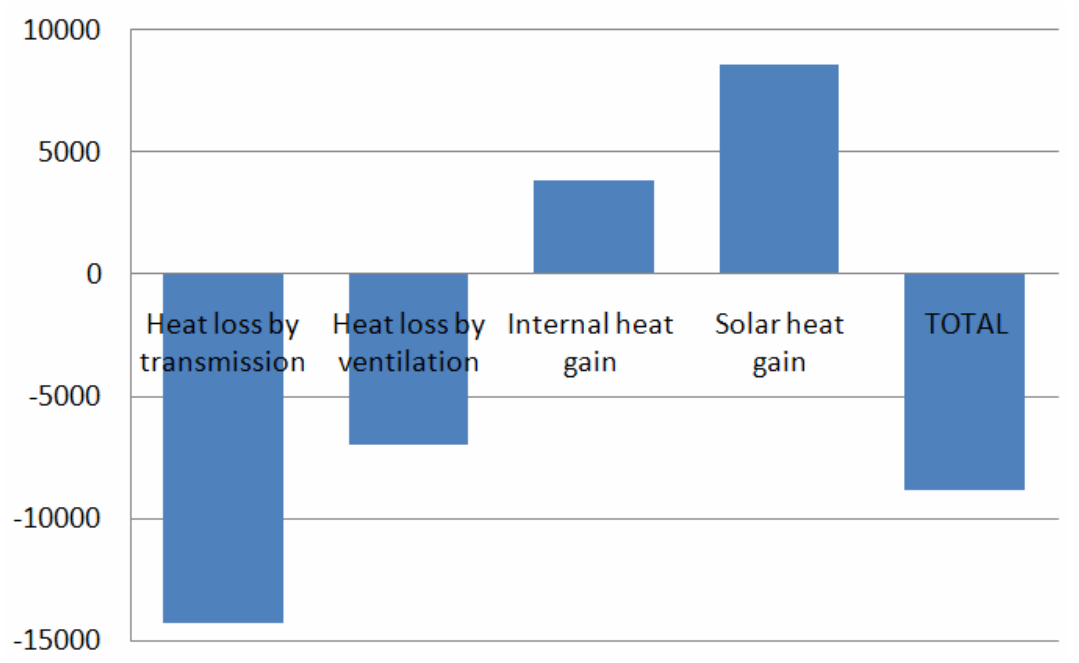

Figure 7. Annual Energy Need for Heating ( $\mathrm{kWh} /$ year)

Regarding the cooling season, the annual energy need for cooling, given by Eq. 3, is summarized in Table 4. 
Table 4. Annual Energy Need for Cooling $\left(\mathrm{Q}_{\mathrm{C}, \mathrm{nd}}\right)$

\begin{tabular}{|c|c|c|}
\hline \multirow{4}{*}{$\begin{array}{c}\text { Heat losses } \\
(\mathrm{kWh} / \text { year })\end{array}$} & Exterior walls & 853.28 \\
\cline { 2 - 3 } & Roof and Terrace & 630.16 \\
\cline { 2 - 3 } & Windows/Doors & 4215.97 \\
\cline { 2 - 3 } & Ventilation & 2789.80 \\
\cline { 2 - 3 } & Total & $\mathbf{8 4 8 9 . 2 1}$ \\
\hline \multirow{3}{*}{$\begin{array}{c}\text { Heat gains } \\
(\mathrm{kWh} / \text { year })\end{array}$} & Walls & 876.64 \\
\cline { 2 - 3 } & Windows & 5840.38 \\
\cline { 2 - 3 } & Internal & 3706.15 \\
\cline { 2 - 3 } & Total & $\mathbf{1 0 4 2 3 . 1 7}$ \\
\hline \multicolumn{2}{|c|}{$\eta$} & 0.58 \\
\hline \multicolumn{2}{|c|}{} & $\mathbf{4 4 2 4 . 5 0}$ \\
\hline
\end{tabular}

The annual energy need for cooling per $\mathrm{m}^{2}$, is given from (15), $N_{v c}=13.98 \mathrm{kWh} / \mathrm{m}^{2}$. Its value is less than the limit value of $N_{v}=18.00 \mathrm{kWh} / \mathrm{m}^{2}$. The net annual energy need for cooling is represented in Figure 8.

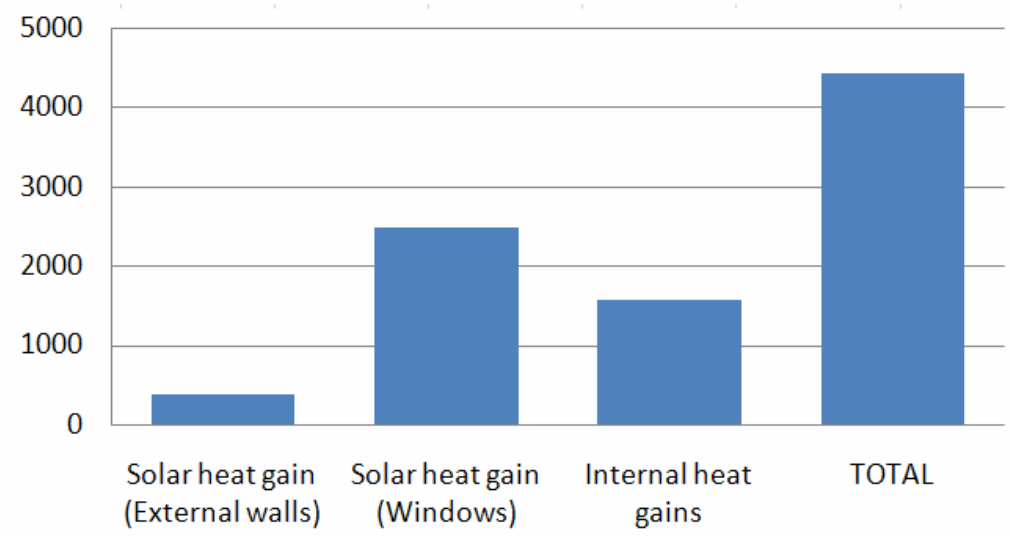

Figure 8. Annual Energy Need for Cooling ( $k$ Wh/year $)$

\subsubsection{Embodied energy}

The quantification of the embodied energy of the building, considering the time period of 50 years, is performed by the Cumulative Energy Demand method and the computer program SimaPro v7.0 [26]. All the inventory data needed for the analysis was supplied by the Ecoinvent database [27]. Similar procedure has been used in other studies comparing the life cycle embodied energy and the operational energy of buildings [28, 29].

The life cycle embodied energy is represented as a tree in Figure 9. The first branch of the tree represents the construction stage, the second the end-of-life stage, and the third brace the operation stage. The thickness of the lines represents the relative importance of each stage to the overall result. Thus, the construction stage contributes with a share of $122 \%$, the use stage with a share of less than $2 \%$, and finally the last stage with a share of $-23 \%$. The minus at the end-of-life stage is the credit given to the recycling of the steel structure. 


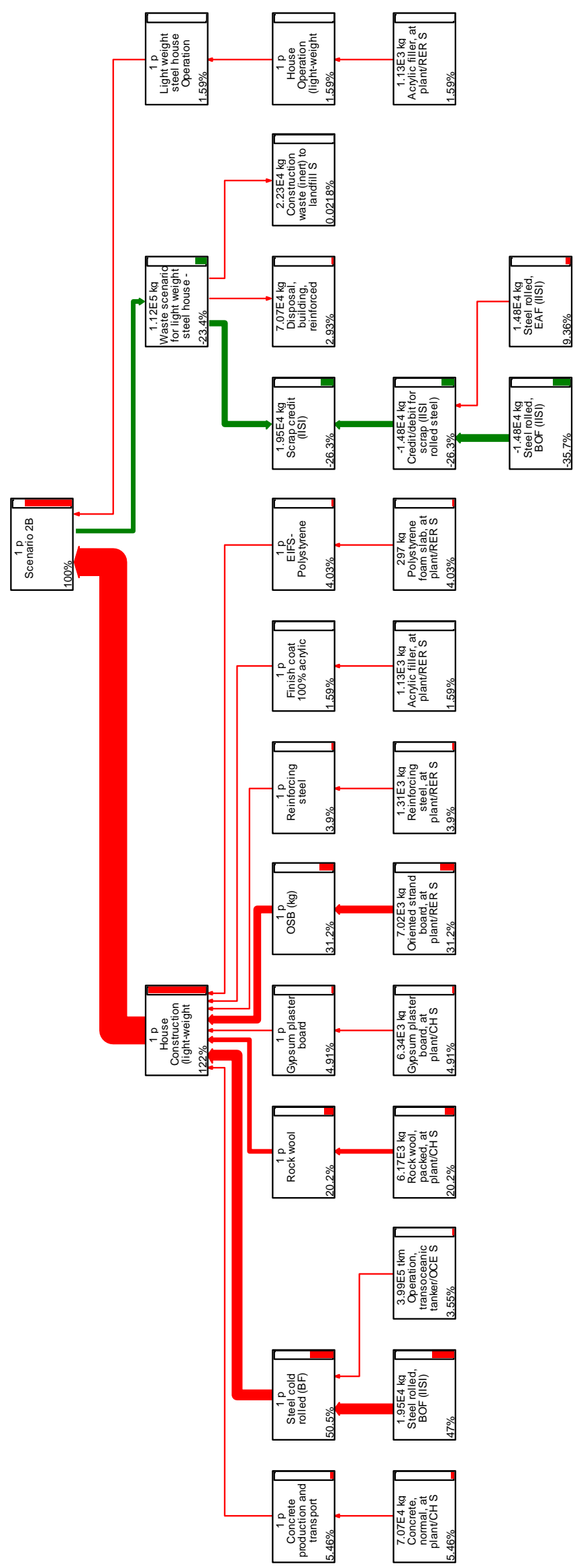

Figure 9. Tree Representation of the Life Cycle Embodied Energy of the Building 


\subsubsection{Comparison between embodied energy and operational energy}

Comparing the energy needed during the operation stage of the building (operational energy) and the embodied energy of the building over the 50 years period, the results are presented in Figure 10.

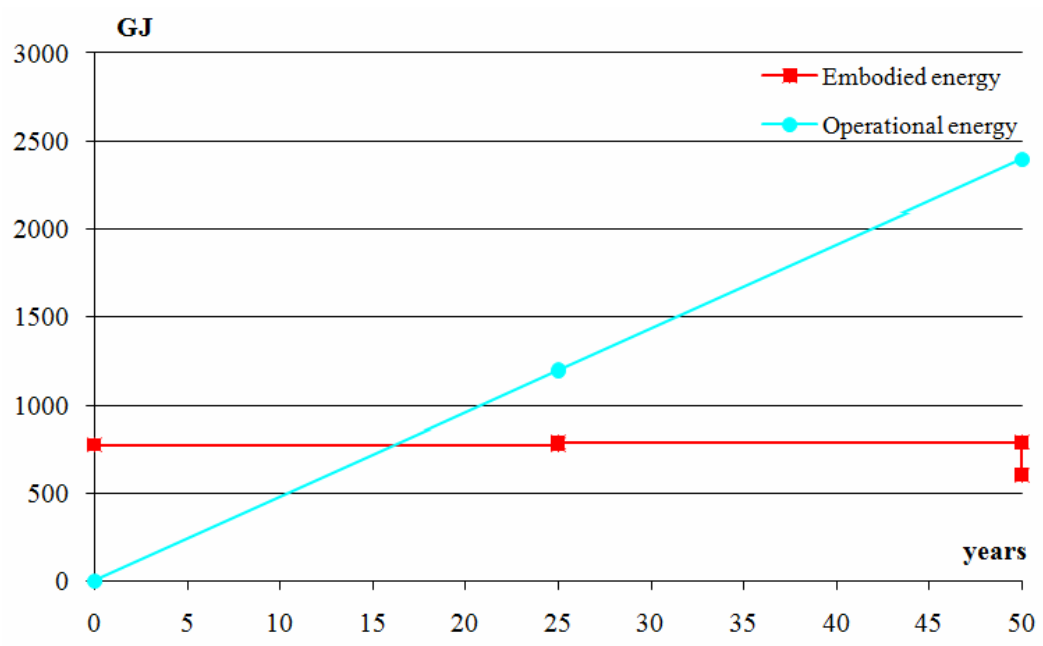

Figure 10. Life Cycle Operational and Embodied Energy

The total life cycle operational energy represents about $80 \%$ of the total life cycle energy. It should be noted that the operational energy, in this case study, includes only the energy needs for heating and cooling. The time period needed for the operational energy to overcome the embodied energy is 16 years.

\section{PARAMETRIC STUDY: INFLUENCE OF LEVEL OF INSULATION}

\subsection{Scenarios}

In order to assess the influence of the level of insulation, several alternative solutions are analysed. The first scenario corresponds to the original solution, where only the external walls have an outside layer of polystyrene with $3 \mathrm{~cm}$, and represents the reference scenario. Scenario 2 corresponds to a lower level of insulation. Scenario 3 corresponds to an increased level of insulation, with the thickness of the layer in the external walls increased to $10 \mathrm{~cm}$, and a layer of polystyrene added to the roof and to the terrace slab, as shown in Figure 11.
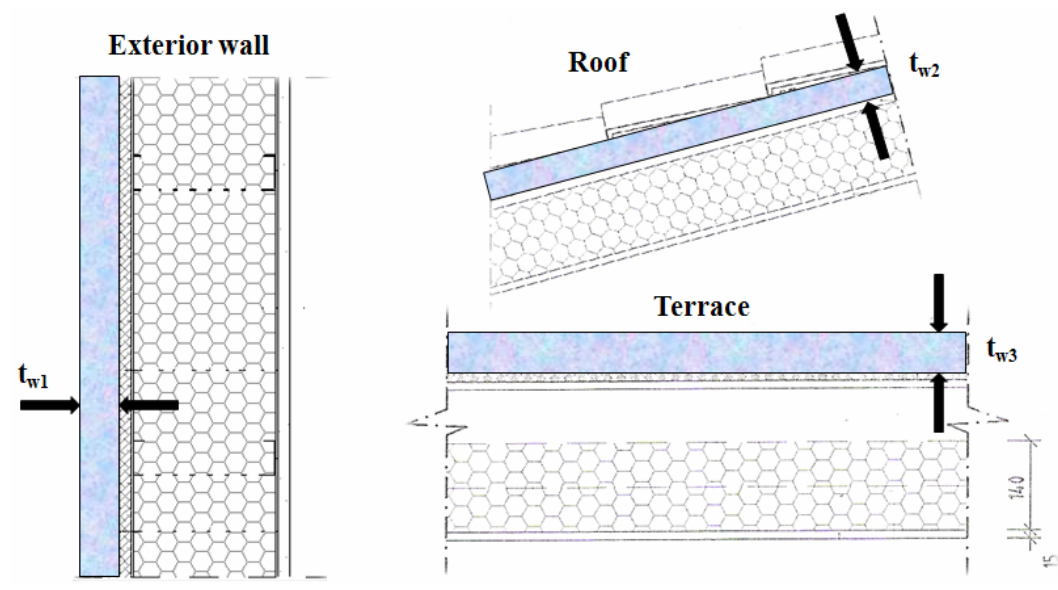

Figure 11. Schemes of the Alternative Scenario 3: $\mathrm{t}_{\mathrm{w} 1}=100 \mathrm{~mm}, \mathrm{t}_{\mathrm{w} 2}=\mathrm{t}_{\mathrm{w} 3}=60 \mathrm{~mm}$ 
Table 5. Level of Insulation for the Various Scenarios and Relative Thermal Transmittances

\begin{tabular}{|l|l|c|c|c|c|c|}
\hline & & Scenario 1 & Scenario 2 & Scenario 3 & Scenario 4 & Scenario 5 \\
\hline \multirow{4}{*}{ Ext. Wall } & Polystyrene $(\mathrm{mm})$ & 30 & 0 & 100 & 100 & 30 \\
\cline { 2 - 7 } & Rock wool $(\mathrm{mm})$ & 140 & 70 & 140 & 140 & 140 \\
\cline { 2 - 7 } & $\mathrm{U}\left(\mathrm{W} / \mathrm{m}^{2} .{ }^{\circ} \mathrm{C}\right)$ & 0.218 & 0.478 & 0.158 & 0.158 & 0.218 \\
\hline \multirow{3}{*}{ Roof } & Polystyrene $(\mathrm{mm})$ & - & - & 60 & 60 & - \\
\cline { 2 - 7 } & Rock wool $(\mathrm{mm})$ & 140 & 70 & 140 & 140 & 140 \\
\cline { 2 - 7 } & $\mathrm{U}\left(\mathrm{W} / \mathrm{m}^{2} .{ }^{\circ} \mathrm{C}\right)$ & 0.262 & 0.482 & 0.188 & 0.188 & 0.262 \\
\hline \multirow{3}{*}{ Werrace } & Polystyrene $(\mathrm{mm})$ & - & - & 60 & 60 & - \\
\cline { 2 - 7 } & Rock wool $(\mathrm{mm})$ & 140 & 70 & 140 & 140 & 140 \\
\cline { 2 - 7 } & $\mathrm{U}\left(\mathrm{W} / \mathrm{m}^{2} .{ }^{\circ} \mathrm{C}\right)$ & 0.253 & 0.456 & 0.184 & 0.184 & 0.253 \\
\hline \multirow{3}{*}{} & $\mathrm{U}\left(\mathrm{W} / \mathrm{m}^{2} .{ }^{\circ} \mathrm{C}\right)$ & 2.733 & 2.733 & 2.733 & 1.900 & 2.733 \\
\cline { 2 - 7 } & Glass solar factor & 0.78 & 0.78 & 0.78 & 0.50 & 0.78 \\
\cline { 2 - 7 } & Shading effect & yes & yes & yes & yes & no \\
\hline
\end{tabular}

Scenario 4 is identical to scenario 3 but with an improvement in the thermal behaviour of the windows. Finally, scenario 5 is similar to scenario 1 but without the shading effect from horizontal overhangs above the windows. The various scenarios are summarized in Table 5. These scenarios will change the amount of the material needed for each solution, which will be taken into consideration for the calculation of the embodied energy for each case. In the following paragraphs, the results obtained for each scenario are presented.

\subsection{Simplified Approach}

The total annual energy need, for the five scenarios defined above, is indicated in Table 6 . The relative values are referred to scenario 1 . It is seen that although the amount of external insulation was more than doubled in scenario 3 , the total energy needs are only reduced by $6 \%$. By comparison, scenario 4 decreases the total energy needs by about $19 \%$, the only difference being the improvement of the thermal properties of the windows. Scenario 2 corresponds to a reduction of the global insulation of the building and results in an increase of $23 \%$ of the total energy needs. Finally, scenario 5, which ignores the shading effect of overhangs above the windows, increases by about $4 \%$ the energy needs.

Table 6. Annual Energy Needs, Per Year, for the Different Scenarios

\begin{tabular}{|l|c|c|c|c|c|c|}
\hline & \multicolumn{2}{|c|}{$\mathbf{Q}_{\mathbf{H}, \mathbf{n}}$} & \multicolumn{2}{c|}{$\mathbf{Q}_{\mathbf{C}, \mathbf{n}}$} & \multicolumn{2}{c|}{ TOTAL/Year } \\
\hline & $(\mathrm{kWh} /$ year$)$ & $\Delta(\%)$ & $(\mathrm{kWh} /$ year $)$ & $\Delta(\%)$ & $(\mathrm{kWh} /$ year $)$ & $\Delta(\%)$ \\
\hline Scenario 1 & 8835.67 & - & 4424.49 & - & 13260.16 & - \\
\hline Scenario 2 & 11829.46 & $33.9 \%$ & 4447.28 & $0.5 \%$ & 16276.73 & $22.7 \%$ \\
\hline Scenario 3 & 8076.21 & $-8.6 \%$ & 4409.20 & $-0.3 \%$ & 12485.41 & $-5.8 \%$ \\
\hline Scenario 4 & 7428.75 & $-15.9 \%$ & 3346.86 & $-24.4 \%$ & 10775.61 & $-18.7 \%$ \\
\hline Scenario 5 & 7824.54 & $-11.4 \%$ & 5897.60 & $33.3 \%$ & 13722.14 & $3.5 \%$ \\
\hline
\end{tabular}


Table 7 and Figure 12 summarize the balance between life cycle embodied energy and life cycle operational energy for the five scenarios. The influence of the degree of insulation results in variations of $+22.7 \%$ and $-18.7 \%$ of the operational energy, with corresponding variations of the embodied energy of $-15.4 \%$ and $+18.3 \%$. Globally, the solution with the best insulation minimizes the total energy $(-11 \%)$. Finally, the operational energy becomes dominant for a service life in excess of 11.7 to 22.9 years and represents, over the service life of 50 years, $73.2 \%$ to $85.2 \%$ of the total life cycle energy, depending on the scenario.

Table 7. Total Life Cycle Operational and Embodied Energies

\begin{tabular}{|l|c|c|c|c|c|c|c|}
\hline & \multicolumn{2}{|c|}{ Operational energy } & \multicolumn{2}{|c|}{ Embodied energy } & TOTAL & \multirow{2}{*}{$\begin{array}{c}\text { Operation } \\
\text { al/Total }\end{array}$} & Balanced \\
\cline { 1 - 6 } & $(\mathrm{GJ})$ & $\Delta$ & $(\mathrm{GJ})$ & $\Delta$ & $(\mathrm{GJ})$ & year \\
\hline Scenario 1 & 2393.53 & - & 601.09 & - & 2994.63 & $79.9 \%$ & 16.3 \\
\hline Scenario 2 & 2938.04 & $\begin{array}{c}22.7 \\
\%\end{array}$ & 508.51 & $-15.4 \%$ & 3446.55 & $85.2 \%$ & 11.7 \\
\cline { 1 - 1 } & & & & & & \\
\hline Scenario 3 & 2253.68 & $-5.8 \%$ & 711.30 & $18.3 \%$ & 2964.99 & $76.0 \%$ & 19.8 \\
\hline Scenario 4 & 1945.06 & $\begin{array}{c}-18.7 \\
\%\end{array}$ & 711.30 & $18.3 \%$ & 2656.36 & $73.2 \%$ & 22.9 \\
\hline Scenario 5 & 2476.92 & $3.5 \%$ & 601.09 & $0 \%$ & 3078.02 & $80.5 \%$ & 15.7 \\
\hline
\end{tabular}

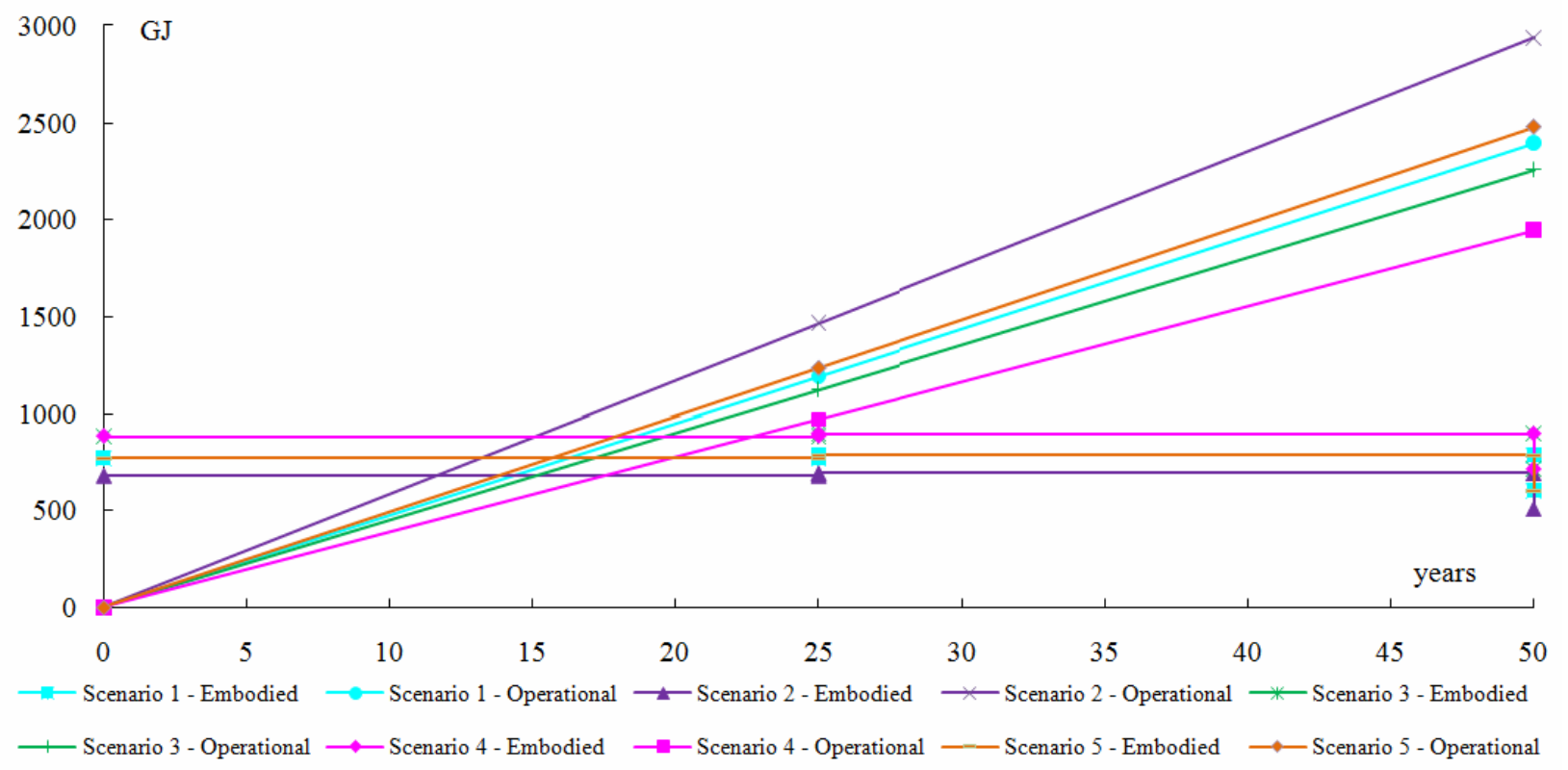

Figure 12. Balance of Life Cycle Embodied Energy and Life Cycle Operational Energy

The parametric study shows that for a standard service life of residential buildings of 50 years, reducing the operating energy is more important than reducing the embodied energy. Furthermore, the solution that minimizes the operating energy also minimizes total lifecycle energy.

It is also well-known that a simplified quasi steady-state approach can be used for a comparative analysis but does not simulate real daily conditions (namely thermal inertia of the building and ventilation are not properly considered in the analysis). Additionally, examination of Table 6 shows a consistent trend for the heating period, but reveals some discrepancies for the cooling period. In order to validate the results obtained with the simplified approach and to overcome some of the limitations indicated, a dynamic simulation analysis is performed for the 5 scenarios indicated in Table 5, and is described in the next paragraphs. 


\subsection{Dynamic Simulation Approach}

\subsubsection{Modelling and analysis options}

The model of the building used for the simulation analysis was presented in Figure 4. The model was assembled using 15 thermal zones, corresponding to the main internal partitions of the building. The ground floor has four thermal zones; the first floor has eight thermal zones, and finally the top floor has two zones (see Figure 5). The stairways and corridors is a thermal zone common to the three floors.

The boundaries of the model were defined in order to consider the same conditions as for the simplified approach. Thus, the thermal transmittance of the elements of the building is indicated in Table 2. The internal heat gains were modelled assuming a value of $4 \mathrm{~W} / \mathrm{m}^{2}$ and the natural ventilation infiltration is considered to be 0.6 air changes per hour. Also, no thermal bridges were considered in the analysis and no losses were considered through the ground floor of the building.

The exterior climatic conditions were simulated using the DesignBuilder weather data for Coimbra (PRT_COIMBRA_IWEC.epw), as illustrated in Figure 6. The simulations were performed on a hourly basis. The results obtained for each scenario are presented in the following paragraphs.

\subsubsection{Simulation under passive thermal conditions}

Figure 13 presents the average temperature inside the building for the 5 scenarios, calculated without the specification of any heating or cooling equipment (passive thermal conditions), summarized in Table 8.

\begin{tabular}{|c|c|c|c|c|c|}
\hline $\begin{array}{l}\text { Average } \\
\text { Operational } \\
\text { Temperature }\left({ }^{\circ} \mathrm{C}\right)\end{array}$ & Scenario 1 & Scenario 2 & Scenario 3 & Scenario 4 & Scenario 5 \\
\hline Annual & 24.17 & 23.19 & 24.51 & 24.77 & 27.06 \\
\hline $\begin{array}{l}\text { Summer } \\
\text { (maximum) }\end{array}$ & $\begin{array}{c}29.57 \\
(36.71) \\
\end{array}$ & $\begin{array}{c}28.75 \\
(36.07) \\
\end{array}$ & $\begin{array}{c}29.84 \\
(36.88) \\
\end{array}$ & $\begin{array}{c}30.09 \\
(36.91) \\
\end{array}$ & $\begin{array}{c}33.03 \\
(41.01) \\
\end{array}$ \\
\hline $\begin{array}{l}\text { Winter } \\
\text { (minimum) }\end{array}$ & $\begin{array}{c}20.85 \\
(15.00)\end{array}$ & $\begin{array}{c}19.72 \\
(13.64)\end{array}$ & $\begin{array}{c}21.26 \\
(15.47)\end{array}$ & $\begin{array}{c}21.53 \\
(15.67)\end{array}$ & $\begin{array}{c}23.20 \\
(16.23)\end{array}$ \\
\hline
\end{tabular}

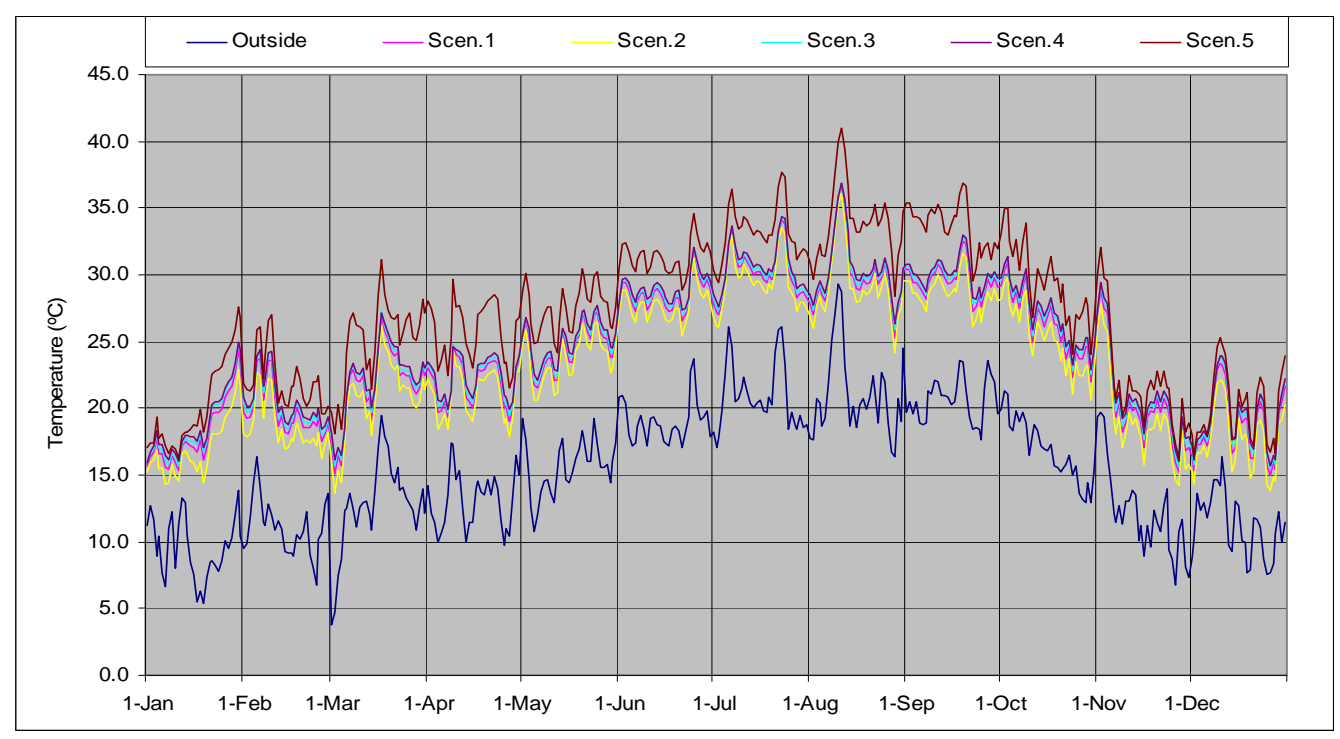

Figure 13. Temperatures Variation Inside and Outside the Building 


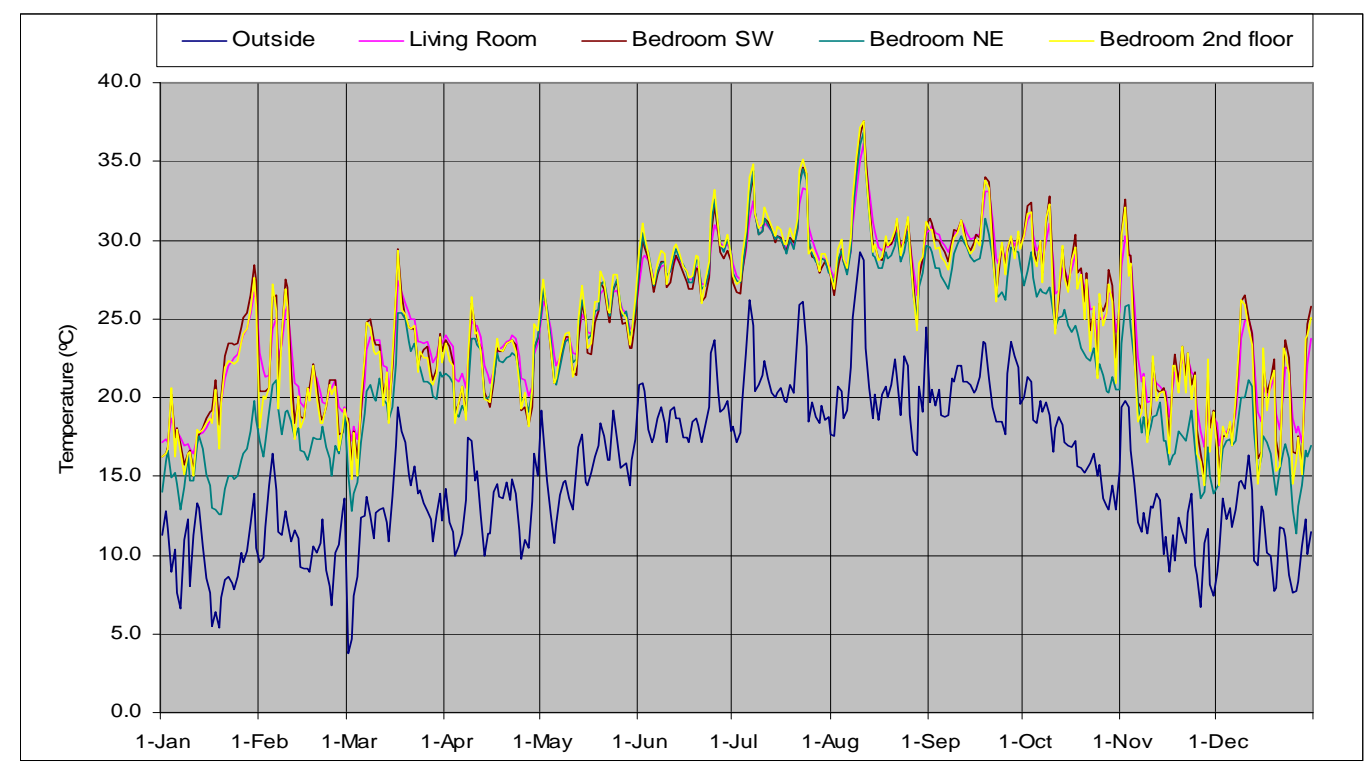

Figure 14. Temperatures Variation Inside and Outside the Building

The variation of the average daily temperatures of Figure 13 shows that for most of the winter period the average temperature is below the set-point temperature of $20^{\circ} \mathrm{C}$. The same conclusion is noted for the summer period, many days having average temperatures above the set-point temperature of $25^{\circ} \mathrm{C}$. Figure 14 illustrates the annual temperature variation for scenario 1 in several compartments. Significant differences are clearly noted (differences of $1.52^{\circ} \mathrm{C}$ and $3.58^{\circ} \mathrm{C}$ for the average summer and winter temperatures, respectively (Table 9).

Table 9. Average Operational Temperatures

\begin{tabular}{|l|c|c|c|c|}
\hline $\begin{array}{l}\text { Average } \\
\text { Operational } \\
\text { Temperature }\left({ }^{\circ} \mathrm{C}\right)\end{array}$ & $\begin{array}{c}\text { Living Room } \\
\text { (ground floor) }\end{array}$ & $\begin{array}{c}\text { Bedroom SE/SW } \\
\left(1^{\text {st }} \text { floor }\right)\end{array}$ & $\begin{array}{c}\text { Bedroom } \\
\text { NW/NE } \\
\left(1^{\text {st }} \text { floor }\right)\end{array}$ & $\begin{array}{c}\text { Bedroom } \\
\left(2^{\text {nd }} \text { floor }\right)\end{array}$ \\
\hline Annual & 25.05 & $24.33 / 24.89$ & $24.05 / 23.01$ & 24.80 \\
\hline $\begin{array}{l}\text { Summer } \\
\text { (maximum) }\end{array}$ & 29.80 & $29.17 / 29.70$ & $30.69 / 29.34$ & 29.96 \\
\hline $\begin{array}{l}\text { Winter } \\
\text { (minimum) }\end{array}$ & $(36.10)$ & $(36.99)(37.53)$ & $(38.98) /(36.83)$ & $(37.61)$ \\
\hline
\end{tabular}

\subsubsection{Heating season}

In order to compare with the RCCTE simulations, Figure 15 presents the results of a simulation for the heating period $\left(1^{\text {st }}\right.$ October to $31^{\text {st }}$ March) assuming that the heating equipment is turned on and off automatically in order to ensure an inside temperature not lower than $20^{\circ} \mathrm{C}$. Tables 10 and 11 allow the comparison of the results of RCCTE with the results from the dynamic simulation. 


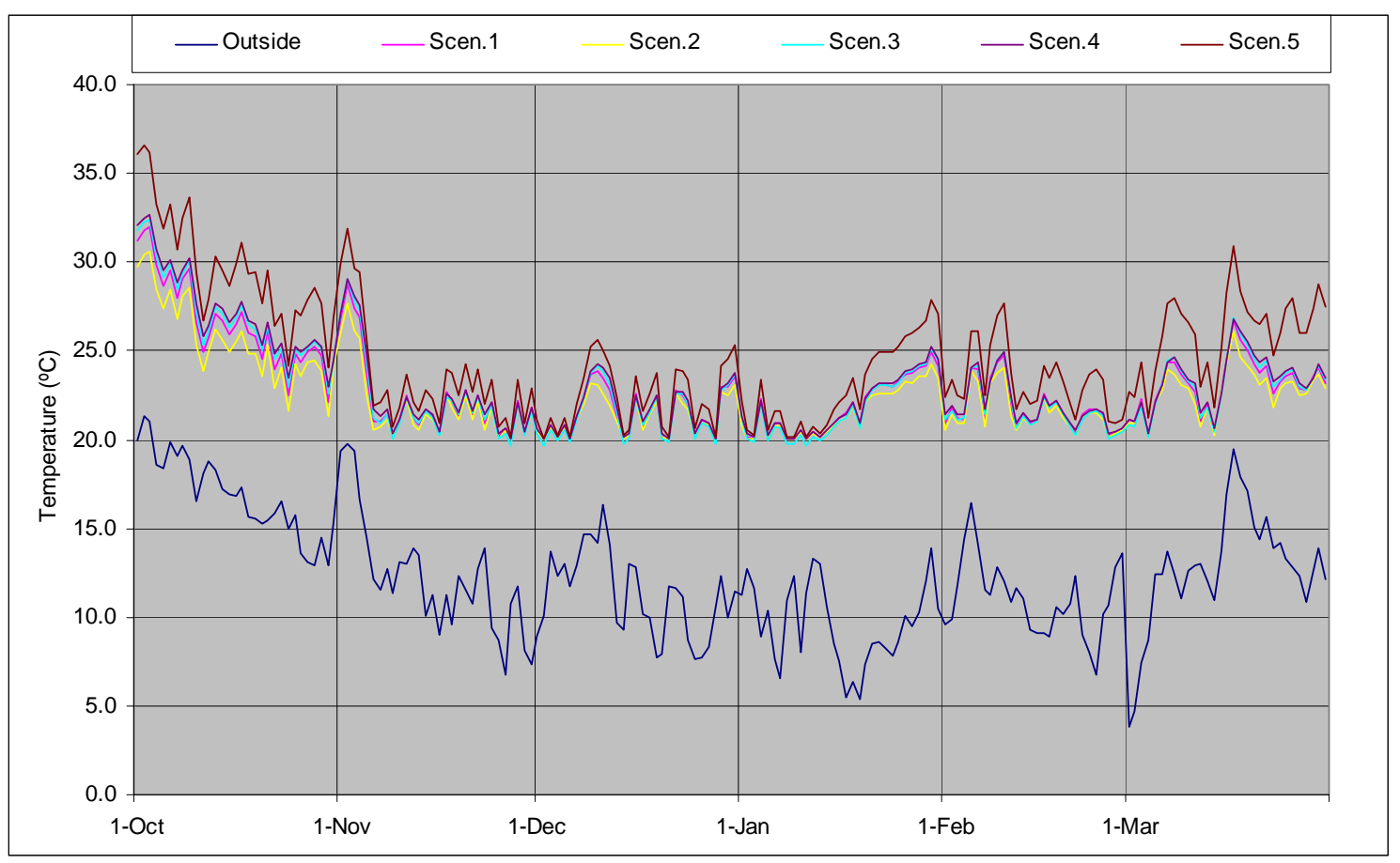

Figure 15. Temperatures Variation Inside and Outside the Building (Winter Season)

Table 10. Annual Heating Energy According to RCCTE

\begin{tabular}{|c|c|c|c|c|c|}
\hline & \multicolumn{5}{|c|}{ RCCTE } \\
\hline $\mathrm{kWh} /$ year & Scenario 1 & Scenario 2 & Scenario 3 & Scenario 4 & Scenario 5 \\
\hline Exterior walls & 2137.86 & 4687.70 & 1549.36 & 1549.36 & 2137.86 \\
\hline Roof and Terrace & 1578.85 & 2881.73 & 1138.69 & 1138.69 & 1578.85 \\
\hline Windows/Doors & 10562.96 & 10562.96 & 10562.96 & 7343.63 & 10562.96 \\
\hline Ventilation & 6989.74 & 6989.74 & 6989.74 & 6989.74 & 6989.74 \\
\hline Total heat loss & $\mathbf{2 1 2 6 9 . 4 1}$ & $\mathbf{2 5 1 2 2 . 1 3}$ & $\mathbf{2 0 2 4 0 . 7 6}$ & $\mathbf{1 7 0 2 1 . 4 3}$ & $\mathbf{2 1 2 6 9 . 4 1}$ \\
\hline Internal & 5468.08 & 5468.08 & 5468.08 & 5468.08 & 5468.08 \\
\hline Solar & 12334.20 & 12334.20 & 12334.20 & 7906.54 & 15105.65 \\
\hline Total heat gains & $\mathbf{1 7 8 0 2 . 2 8}$ & $\mathbf{1 7 8 0 2 . 2 8}$ & $\mathbf{1 7 8 0 2 . 2 8}$ & $\mathbf{1 3 3 7 4 . 6 2}$ & $\mathbf{2 0 5 7 3 . 7 3}$ \\
\hline$\eta$ & 0.70 & 0.75 & 0.68 & 0.72 & 0.65 \\
\hline Heating energy & $\mathbf{8 8 3 5 . 6 7}$ & $\mathbf{1 1 8 2 9 . 4 6}$ & $\mathbf{8 0 7 6 . 2 1}$ & $\mathbf{7 4 2 8 . 7 5}$ & $\mathbf{7 8 2 4 . 5 3}$ \\
\hline
\end{tabular}

Table 11. Annual Heating Energy According to EnergyPlus

\begin{tabular}{|c|c|c|c|c|c|}
\hline & \multicolumn{5}{|c|}{ DsB (E+) } \\
\hline kWh/year & Scenario 1 & Scenario 2 & Scenario 3 & Scenario 4 & Scenario 5 \\
\hline Exterior walls & 2087.46 & 4245.81 & 1528.05 & 1548.50 & 2438.26 \\
\hline Roof and Terrace & 1685.96 & 2828.09 & 1231.63 & 1240.57 & 2059.67 \\
\hline Windows/Doors & 8865.79 & 8457.01 & 8889.36 & 5625.42 & 10474.45 \\
\hline Ventilation & 8079.469 & 7870.963 & 8065.089 & 8201.21 & 9323.051 \\
\hline Total heat loss & $\mathbf{2 0 7 1 8 . 6 8}$ & $\mathbf{2 3 4 0 1 . 8 8}$ & $\mathbf{1 9 7 1 4 . 1 4}$ & $\mathbf{1 6 6 1 5 . 7 0}$ & $\mathbf{2 4 2 9 5 . 4 4}$ \\
\hline Internal & 5715.439 & 5715.439 & 5715.439 & 5715.439 & 5715.439 \\
\hline Solar & 11175.87 & 11175.87 & 11175.87 & 8518.763 & 16097.5 \\
\hline Total heat gains & $\mathbf{1 6 8 9 1 . 3 1}$ & $\mathbf{1 6 8 9 1 . 3 1}$ & $\mathbf{1 6 8 9 1 . 3 1}$ & $\mathbf{1 4 2 3 4 . 2}$ & $\mathbf{2 1 8 1 2 . 9 4}$ \\
\hline Heating energy & $\mathbf{3 8 2 7 . 3 7}$ & $\mathbf{6 5 1 0 . 5 7}$ & $\mathbf{2 8 2 2 . 8 3}$ & $\mathbf{2 3 8 1 . 5 0}$ & $\mathbf{2 4 8 2 . 5 0}$ \\
\hline Other & 389.22 & 425.08 & 384.23 & 359.07 & 549.33 \\
\hline Total HE & $\mathbf{4 2 1 6 . 6 0}$ & $\mathbf{6 9 3 5 . 6 5}$ & $\mathbf{3 2 0 7 . 0 6}$ & $\mathbf{2 7 4 0 . 5 7}$ & $\mathbf{3 0 3 1 . 8 3}$ \\
\hline
\end{tabular}


Reasonable agreement (same trend) is noted for the heat losses for the exterior walls, roof and terrace (except scenario 5 and heat gains (internal and solar), while windows/doors losses and ventilation losses do not correlate so well). Global results present the same trend but the numerical results are over-estimated by RCCTE by a two to one ratio.

\subsubsection{Cooling season}

Similarly, in order to compare with the RCCTE simulations, Figure 16 presents the results of a simulation for the cooling period ( $1^{\text {st }}$ June to $30^{\text {st }}$ September) assuming that the cooling equipment is turned on and off automatically in order to ensure an inside temperature not higher than $25^{\circ} \mathrm{C}$.

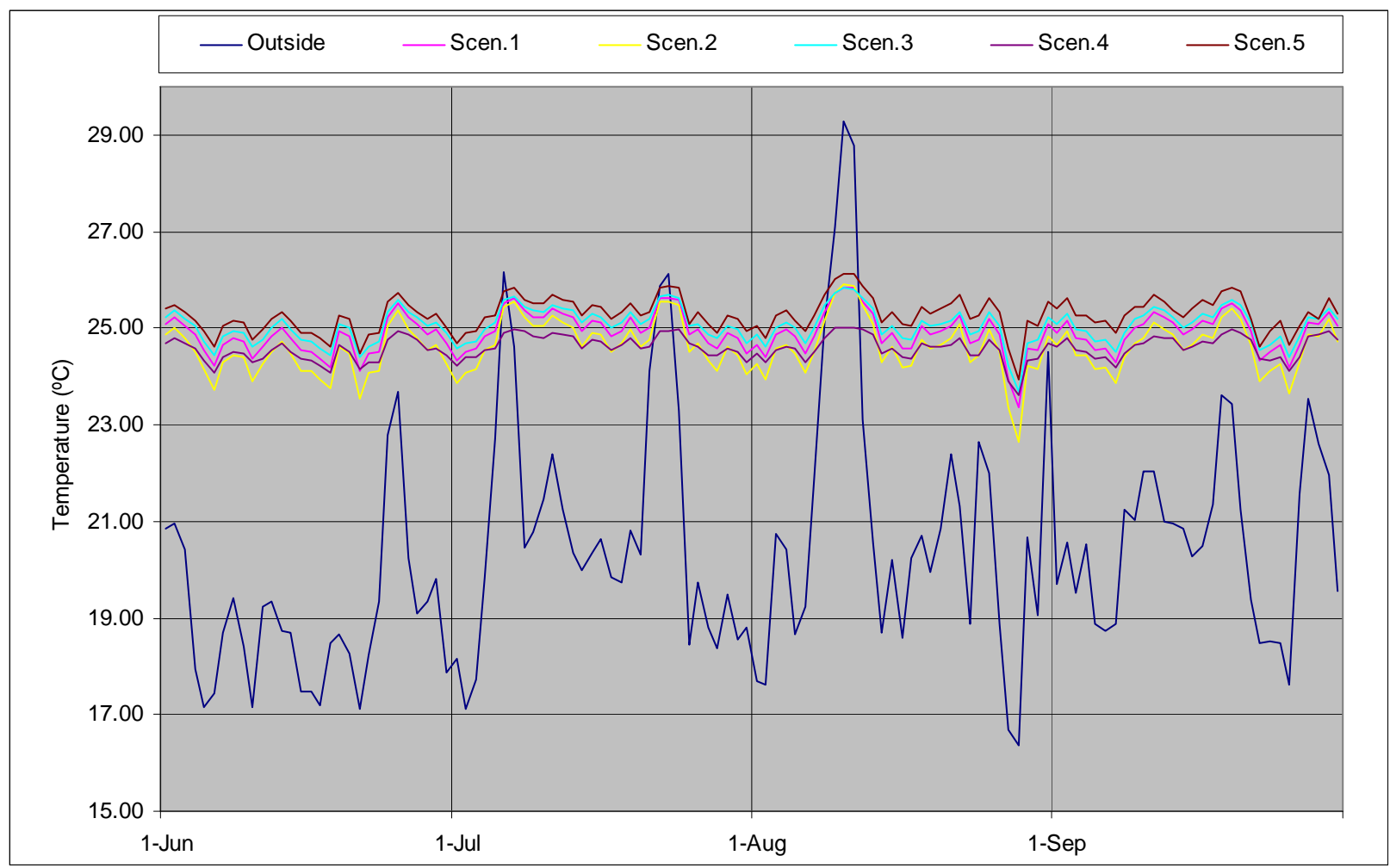

Figure 16. Temperatures Variation Inside and Outside the Building (Summer Season)

Table 12. Annual Cooling Energy According to RCCTE

\begin{tabular}{|c|c|c|c|c|c|}
\hline & \multicolumn{5}{|c|}{ RCCTE } \\
\hline kWh/year & Scenario 1 & Scenario 2 & Scenario 3 & Scenario 4 & Scenario 5 \\
\hline Exterior walls & 853.28 & 1870.99 & 618.39 & 618.39 & 853.28 \\
\hline Roof and Terrace & 630.16 & 1150.18 & 454.48 & 454.48 & 630.16 \\
\hline Windows/Doors & 4215.97 & 4215.97 & 4215.97 & 2931.05 & 4215.97 \\
\hline Ventilation & 2789.80 & 2789.80 & 2789.80 & 2789.80 & 2789.80 \\
\hline Total heat loss & $\mathbf{8 4 8 9 . 2 1}$ & $\mathbf{1 0 0 2 6 . 9 4}$ & $\mathbf{8 0 7 8 . 6 5}$ & $\mathbf{6 7 9 3 . 7 2}$ & $\mathbf{8 4 8 9 . 2 1}$ \\
\hline Walls & 876.64 & 1714.09 & 633.37 & 633.37 & 876.64 \\
\hline Windows & 5840.38 & 5840.38 & 5840.38 & 3743.83 & 7714.59 \\
\hline Internal & 3706.15 & 3706.15 & 3706.15 & 3706.15 & 3706.15 \\
\hline Total heat gains & $\mathbf{1 0 4 2 3 . 1 7}$ & $\mathbf{1 1 2 6 0 . 6 2}$ & $\mathbf{1 0 1 7 9 . 9 0}$ & $\mathbf{8 0 8 3 . 3 5}$ & $\mathbf{1 2 2 9 7 . 3 8}$ \\
\hline$\eta$ & 0.58 & 0.61 & 0.57 & 0.59 & 0.52 \\
\hline Cooling energy & $\mathbf{4 4 2 4 . 5 0}$ & $\mathbf{4 4 4 7 . 2 8}$ & $\mathbf{4 4 0 9 . 2 0}$ & $\mathbf{3 3 4 6 . 8 6}$ & $\mathbf{5 8 9 7 . 6 0}$ \\
\hline
\end{tabular}


The results of RCCTE and the results from the dynamic simulation are indicated in Tables 12 and 13, respectively. In this case, the comparison is not so straightforward since RCCTE considers both heat losses and heat gains through the walls. Global results indicate higher cooling energy needs (about 100\% higher) according to the dynamic simulation. In addition, scenario 4 (the best insulated solution) does not present the best performance.

Table 13. Annual Cooling Energy According to EnergyPlus

\begin{tabular}{|c|c|c|c|c|c|}
\hline & \multicolumn{5}{|c|}{ DsB (E+) } \\
\hline kWh/year & Scenario 1 & Scenario 2 & Scenario 3 & Scenario 4 & Scenario 5 \\
\hline Exterior walls & 170.54 & 238.15 & 149.35 & 91.32 & 109.78 \\
\hline Roof and & 38.79 & 166.72 & 5.39 & 42.03 & -10.26 \\
\hline Windows/Doors & 2198.98 & 2035.43 & 2284.29 & 509.19 & 1917.92 \\
\hline Ventilation & 2066.55 & 1920.75 & 2138.18 & 1917.19 & 2115.62 \\
\hline Total heat loss & $\mathbf{4 4 7 4 . 8 6}$ & $\mathbf{4 3 6 1 . 0 5}$ & $\mathbf{4 5 7 7 . 2 1}$ & $\mathbf{2 5 5 9 . 7 3}$ & $\mathbf{4 1 3 3 . 0 6}$ \\
\hline Windows & 7510.87 & 7510.87 & 7510.87 & 5643.84 & 12063.65 \\
\hline Internal & 3895.44 & 3895.44 & 3895.44 & 3895.44 & 3895.44 \\
\hline Total heat & $\mathbf{1 1 4 0 6 . 3 1}$ & $\mathbf{1 1 4 0 6 . 3 1}$ & $\mathbf{1 1 4 0 6 . 3 1}$ & $\mathbf{9 5 3 9 . 2 8}$ & $\mathbf{1 5 9 5 9 . 0 9}$ \\
\hline Cooling energy & $\mathbf{6 9 3 1 . 4 5}$ & $\mathbf{7 0 4 5 . 2 6}$ & $\mathbf{6 8 2 9 . 1 0}$ & $\mathbf{6 9 7 9 . 5 5}$ & $\mathbf{1 1 8 2 6 . 0 3}$ \\
\hline Other & -414.37 & -148.28 & -488.09 & -388.70 & -671.17 \\
\hline Total CE & $\mathbf{6 5 1 7 . 0 7 8}$ & $\mathbf{6 8 9 6 . 9 7 7}$ & $\mathbf{6 3 4 1 . 0 1}$ & $\mathbf{6 5 9 0 . 8 5 3}$ & $\mathbf{1 1 1 5 4 . 8 6}$ \\
\hline
\end{tabular}

\section{CONCLUSIONS}

In this work the life cycle energy analysis (LCEA) for a light steel residential building constructed in Portugal was performed in order to assess the influence of thermal insulation on the balance between embodied and operational energy. Besides the real thermal insulation adopted on this building, other scenarios were simulated including lower and higher insulation of opaque and transparent building components. Two different approaches were used to compute the building operational energy: RCCTE (Portuguese code of practice, that corresponds to the transposition of the simplified quasi-steady-state analysis procedures specified in ISO 13790) and advanced dynamic simulation analysis using the EnergyPlus software.

The RCCTE Portuguese methodology is based on the EN ISO 13790 standard and uses a quasi-steady approach, where thermal inertia effects are neglected. Results are provided for annual averages. EnergyPlus adopts a sub-dynamic approach, in a sub-hourly basis. Both these models were applied to a single-family dwelling building with a quite complex layout. Thermal loads for the heating and the cooling season were computed using the two approaches. The heat gains component showed a good agreement between the two, but the prediction values for the heat losses with RCCTE are significantly higher than those obtained with EnergyPlus, specially the component due to losses through the walls. These differences are certainly due to the complexity of the adopted geometry. Interaction effects between building regions are certainly not fully taken into account when using integral approaches such as those adopted by these models. Future research will include the study of simpler buildings and compartments, to better establish the differences between predictions and their relation to the characteristics of the geometry. CFD (computational fluid dynamics) simulations are also planned, to provide reference values. 
The LCEA indicate that operational energy (only heating and cooling) represents a very significant share $(80 \%)$ of the building total life cycle energy, 16 years being the time needed for the operational energy to overcome the embodied energy. As expected, when improving the insulation, there is a longer delay for the operational energy to overcome the embodied energy (up to 23 years) and the operational energy share decreases to about $73 \%$ of total life cycle energy.

The different thermal insulating scenarios studied show the importance of improving the thermal performance of "weaker components", i.e., insulation improvement should be preferably directed towards the less performing components, such as windows, potentially leading to operational energy savings of about $20 \%$ for the same occupant's thermal comfort. Over the entire LCEA this reduction represents a decrease of about $11.5 \%$ of total energy (embodied and operational).

These findings show, even with only one case study, that for climatic conditions typical of southern Europe it is possible to improve significantly the thermal efficiency of residential buildings optimizing the insulation materials distribution along the building envelop, paying particularly attention to transparent building components (e.g. windows and doors). This optimization can be accomplished without increasing significantly the embodied energy of the building that takes a bigger share (with the potential to achieve a share of 50\%) in the total life-cycle building energy.

\section{ACKNOWLEDGEMENTS}

Financial support from the Portuguese Ministry of Science and Higher Education (Ministério da Ciência e Ensino Superior) under contract grant SFRH/BD/18801/2004 is gratefully acknowledged.

\section{REFERENCES}

[1] $\operatorname{COM(2004)60,~"Communication~from~the~Commission~to~the~Council,~the~European~}$ Parliament", The European Economic and Social Committee and the Committee of the Regions: Towards a Thematic Strategy on the Urban Environment, Brussels, 2004.

[2] Debnath, A., Singh, S.V. and Singh, Y.P., "Comparative Assessment of Energy Requirements for Different Types of Residential Buildings in India, Energy and Buildings", 1995, Vol. 23, pp. 141-146.

[3] Adalberth, K., "Energy Use During the Life Cycle of Buildings: A Method, Building and Environment, 1997, Vol. 32, No. 4, pp. 317-320.

[4] Adalberth, K., "Energy Use During the Life Cycle of Single-unit Dwellings: Examples", Building and Environment, 1997, Vol. 32, No. 4, pp. 321-329.

[5] Cole, R.J., "Energy and Greenhouse Gas Emissions Associated with the Construction of Alternative Structural Systems", Building and Environment, 1999, Vol. 34, No. 3, pp.335-348.

[6] Eaton, K.J. and Amato, A., "A Comparative Life Cycle Assessment of Steel and Concrete Framed Office Buildings", J. Construct. Steel Res., 1998, Vol. 46, No. 1-3, pp. 286-287.

[7] Yohanis, Y.G. and Norton, B., "Life-cycle Operational and Embodied Energy for a Generic Single-storey Office Building in the UK”, Energy, 2002, Vol. 27, pp. 77-92.

[8] Hacker, J.N., De Saulles, T.P., Minson, A.J., Holmes, M.J., "Embodied and Operational Carbon Dioxide Emissions from Housing: A Case Study on the Effects of Thermal Mass and Climate Change, Energy and Buildings, 2008, Vol. 40, pp. 375-384.

[9] Utama, A. and Gheewala, S.H., "Life Cycle Energy of Single Landed Houses in Indonesia, Energy and Buildings, 2008, Vol. 40, pp. 1911-1916.

[10] Huberman, N. and Pearlmutter, D., "A Life-cycle Energy Analysis of Building Materials in the Negev Desert, Energy and Buildings”, 2008, Vol. 40, pp. 837-848. 
[11] IPCC. 2007, "Climate change 2007: The physical science basis. Contribution of Working Group I to the Fourth Assessment Report of the IPCC", Cambridge University Press. Cambridge, United Kingdom and New York, NY, USA, 2007.

[12] http://www.greenhouse.gov.au/yourhome/technical/fs31.htm. Last accessed in 07/09/18.

[13] IISI. 2002, “World Steel Life Cycle Inventory. Methodology report 1999/2000”, Committee on Environmental Affairs, Brussels, 2002.

[14] European Directive 2002/91/CE. 2002, "Directive 2002/91/CE of the European Parliament and of the Council of 16 December 2002 on the Energy Performance of Buildings".

[15] EN ISO 13790, 2008, "Energy Performance of Buildings - Calculation of Energy Use for Space Heating and Cooling", International Organization for Standardization, Geneva, Switzerland.

[16] Decreto-Lei nº0/2006, "Regulamento das Características Térmicas dos Edifícios (RCCTE)" (in Portuguese).

[17] Decreto-Lei n79/2006, "Regulamento dos Sistemas Energéticos e de Climatização dos Edifícios (RSECE) (in Portuguese).

[18] Website Software DesignBuilder: http://www.designbuilder.co.uk/.

[19] Website Software Energy Plus: http://www.energyplus.gov.

[20] Crawley, D., et al., "EnergyPlus: Creating a New-generation Building Energy Simulation Program, Energy and Buildings, 2001, Vol. 33, pp. 319-331.

[21] Crawley, D., Hand, J., Kummert, M. and Griffith, B., "Contrasting the Capabilities of Building Energy Performance Simulation Programs", Building and Environment, 2008, Vol. 43, pp. 661-673.

[22] Tronchin, L. and Fabbri, K., "Energy Performance Building Evaluation in Mediterranean Countries: Comparison between Software Simulations and Operating Rating Simulation", Energy and Buildings, 2008, Vol. 40, pp. 1176-1187.

[23] Loutzenhiser, P., Manz, H., Moosberger, S. and Maxwell, G., "An Empirical Validation of Window Solar Gain Models and the Associated Interactions", International Journal of Thermal Sciences, 2009, Vol. 48, pp. 85-95.

[24] EN 1993-1-3, Eurocode 3, "Design of Steel Structures - Part 1.3: General Rules Supplementary Rules for Cold-formed Members and Sheeting", European Committee for Standardization, Brussels, 2006.

[25] Instituto de Meteorologia, Portugal, http://www.meteo.pt/pt/oclima/normais/

[26] SimaPro 7, "Software and Database Manual", PRé Consultants, Amersfoort, The Netherlands, 2008.

[27] Frischknecht, R., Jungbluth, N., Althaus, H.-J., Doka, G., Dones, R., Hellweg, S., Hischier, R., Nemecek, T., Rebitzer, G. and Spielmann, M., "Code of Practice", Ecoinvent Report No. 2, Swiss Center for Life Cycle Inventories, Dübendorf, 2004.

[28] Bribián, I., Usón, A., Scarpellini, S. 2009, "Life Cycle Assessment in Buildings: State-of-the-art and Simplified LCA Methodology as a Complement for Building Certification", Building and Environment, Vol. 44, pp. 2510-2520.

[29] Thormark, C. 2002, "A Low Energy Building in a Life Cycle - Its Embodied Energy, Energy need for Operation and Recycling Potential", Building and Environment, Vol. 37, pp. 429-435. 